\title{
Complexation of Mn(II) by Rigid Pyclen Diacetates: Equilibrium, Ki- netic, Relaxometric, DFT and SOD Activity Studies.
}

\author{
Zoltán Garda, ${ }^{\dagger}$ Enikő Molnár, ${ }^{\dagger}$ Nadège Hamon, ${ }^{\ddagger}$ José Luis Barriada, ${ }^{+}$David Esteban-Gómez, ${ }^{+}$Ba- \\ lázs Váradi, ${ }^{\dagger}$ Viktória Nagy, ${ }^{\dagger}$ Kristof Pota, ${ }^{\dagger}, \neq$ Ferenc Krisztián Kálmán, ${ }^{\dagger}$ Imre Tóth, ${ }^{\dagger}$ Norbert \\ Lihi, ${ }^{*}$ Carlos Platas-Iglesias, ${ }^{*++}$ Éva Tóth,§ Raphaël Tripier, ${ }^{* \neq}$ and Gyula Tircsó ${ }^{* \dagger}$ \\ † Department of Physical Chemistry, \# Department of Inorganic and Analytical Chemistry, Faculty of Science and Technology, \\ University of Debrecen, Egyetem tér 1, H-4032 Debrecen, Hungary \\ * Current address of the author: Department of Chemistry and Biochemistry, Texas Christian University, 2950 W. Bowie, Fort \\ Worth, Texas 76109, United States \\ ‡ Univ Brest, UMR-CNRS 6521 CEMCA, 6 avenue Victor le Gorgeu, 29238 Brest, France \\ + Centro de Investigacións Científicas Avanzadas (CICA) and Departamento de Química, Universidade da Coruña, Campus da \\ Zapateira, Rúa da Fraga 10, 15008 A Coruña, Spain. \\ $\S$ Centre de Biophysique Moléculaire, CNRS, rue Charles Sadron, 45071 Orléans, Cedex 2, France
}

\begin{abstract}
We report the Mn(II) complexes with two pyclen-based ligands (pyclen = 3,6,9,15-tetraazabicyclo[9.3.1]pentadeca-1(15),11,13-triene) functionalized with acetate pendant arms either at positions 3,6 (3,6-PC2A) or 3,9 (3,9-PC $2 \mathrm{~A})$ of the macrocyclic fragment. The 3,6-PC2A ligand was synthesized in five steps from pyclen-oxalate by protecting one of the secondary amine groups of pyclen using Alloc protecting chemistry. The complex with 3,9-PC2A is characterized by a higher thermodynamic stability $\left(\log K_{\mathrm{MnL}}=17.09(2)\right.$ than the 3,6-PC2A analogue $\left(\log K_{\mathrm{MnL}}=15.53(1), 0.15 \mathrm{M} \mathrm{NaCl}\right)$. Both complexes contain a water molecule coordinated to the metal ion, which results in relatively high ${ }^{1} \mathrm{H}$ relaxivities $\left(r_{1 \mathrm{p}}=2.72\right.$ and 2.91 $\mathrm{mM}^{-1} \mathrm{~s}^{-1}$ for the complexes with 3,6- and 3,9-PC2A, respectively, ${ }^{2} 5^{\circ} \mathrm{C}, 0.49 \mathrm{~T}$ ). The coordinated water molecule displays fast exchange kinetics with the bulk in both cases; the rates $\left(k_{\mathrm{ex}^{298}}\right)$ are $140 \times 10^{6}$ and $126 \times 10^{6} \mathrm{~s}^{-1}$ for $[\mathrm{Mn}(3,6-\mathrm{PC} 2 \mathrm{~A})]$ and $\left[\mathrm{Mn}\left(3,9^{-}\right.\right.$ PC2A)], respectively. The two complexes were found to be remarkably inert with respect to their dissociation, with halflives of 63 and $21 \mathrm{~h}$, respectively, at $\mathrm{pH} 7.4$ in the presence of excess $\mathrm{Cu}(\mathrm{II})$. The $r_{1 \mathrm{p}}$ values recorded in blood serum remain constant at least over a period of $120 \mathrm{~h}$. Cyclic voltammetry experiments show irreversible oxidation features shifted to higher potentials with respect to $[\mathrm{Mn}(\mathrm{EDTA})]^{2-}$ and $[\mathrm{Mn}(\mathrm{PhDTA})]^{2-}$, indicating that the $\mathrm{PC}_{2} \mathrm{~A}$ complexes reported here have a lower tendency to stabilize $\mathrm{Mn}(\mathrm{III})$. The superoxide dismutase activity of the $\mathrm{Mn}(\mathrm{II})$ complexes was tested using the xanthine/xanthine oxidase/NBT assay at $\mathrm{pH}$ 7.8. The $\mathrm{Mn}(\mathrm{II})$ complexes of 3,6-PC2A and 3,9-PC2A are capable to assist the decomposition of superoxide anion radical. The kinetic rate constant of the complex of $3,9-\mathrm{PC}_{2} \mathrm{~A}$ is smaller by one order of magnitude than that of 3,6-PC2A.
\end{abstract}

\section{INTRODUCTION}

Complexes of $\mathrm{Mn}(\mathrm{II})$ containing a bound water molecule in its coordination sphere have attracted considerable attention recently, as they have been considered as potentially safe alternatives to Gd(III)-based Magnetic Resonance Imaging (MRI) contrast agents (CA).$^{1-3}$ In spite of the large efforts dedicated to the research conducted in the past 8-10 years, only a few ligand candidates represent an acceptable compromise between the seemingly contradictory requirements that need to be fulfilled for safe in vivo applications. The $\mathrm{Mn}(\mathrm{II})$ ion in the majority of its complexes formed with aminopolycarboxylate (APC) ligands is hexa- or heptacoordinated. ${ }^{4,5}$ Therefore potentially pentaor hexadentate ligands can be considered for $\mathrm{Mn}$ (II) complexation to achieve high relaxivities owing to a water molecule bound to the metal ion (inner sphere contribution). ${ }^{1}$ On the other hand, high thermodynamic and redox stability, as well as kinetic inertness, are required to overcome toxicity issues associated to the administration of the $\mathrm{Mn}(\mathrm{II})$ ion in high concentration (necessary for MRI applications). ${ }^{6} \mathrm{Mn}$ (II) accumulation in the brain causes a neurological disorder known as manganism, expressing symptoms similar to Parkinson's disease. ${ }^{7}$ Therefore, among the effective (i.e. high relaxivity) agents, only complexes possessing high stability and most importantly inertness can 
be considered as plausible candidates for CA research. However Mn(II) complexes in general are known to be labile. Among the recently studied systems there are very few inert $\mathrm{Mn}$ (II) complexes. $^{8}$ Within the group of open-chain ligands, the rigid $\mathrm{CDTA}^{9}$ and its derivatives (i.e. $\left.\mathrm{PyC}_{3} \mathrm{~A}\right)^{10}$ or PhDTA ${ }^{11}$ complexes (Chart 1) display the best features. The acyclic $\left[\mathrm{Mn}\left(\mathrm{PyC}_{3} \mathrm{~A}\right)\right]^{-}$chelate has similar relaxation properties to that of [Gd(DTPA) $]^{2-}$ and it is also efficiently eliminated from rats following its intravenous injection. ${ }^{12}$ Because of advantageous properties of the $\mathrm{Mn}$ (II) complexes, bifunctional ligands derived from trans-cyclohexane-1,2-diamine have also been prepared and characterized. ${ }^{13}$ Moreover agents allowing for the visualization of specific organs (i.e. liver) have also been designed and characterized recently. ${ }^{14}$ Physicochemical characterization of $\mathrm{Gd}(\mathrm{III})$ complexes have shown that the complexes of macrocyclic ligands display much better properties as far as the thermodynamics and especially the dissociation kinetics concerns. ${ }^{15}$ The majority of macrocyclic Mn(II) complexes possess either low relaxivity (i.e. non-aquated but inert $[\mathrm{Mn}(\mathrm{DOTA})]^{2-}$ or $[\mathrm{Mn}(\mathrm{PCTA})]^{-}$chelates $)^{16}$ or limited inertness (bisaquated $\mathrm{Mn}$ (II) complexes of 15-membered macrocyclic ligands such as ${ }_{15} \mathrm{Py}-\mathrm{aneN}_{5}$ or $\left.{ }_{15} \mathrm{Py}-\mathrm{aneN}_{3} \mathrm{O}_{2}\right),{ }^{17}$ which limits their potential in vivo application. An acceptable compromise has recently been evidenced for the complexes of 1,4-DO2A and its amide derivatives $\left(1,4^{-}\right.$ $\left.\mathrm{DO}_{2} \mathrm{AM}^{\mathrm{Me} 2}\right) .{ }^{18,19}$ These stable and inert chelates contain an average of 0.9 bound water molecule, therefore they possess only moderate relaxation enhancement. However it can substantially be enhanced (as for 1,4-DO2AM ${ }^{\mathrm{Me} 2}$ ) with non-covalent binding to macromolecules such as human serum albumin (HSA). ${ }^{20}$ The most inert $\mathrm{Mn}$ (II) complex was recently described by É Tóth et al., which is a Mn(II) chelate formed with a 2,4-pyridyl-disubstituted bispidol ligand. ${ }^{8}$

Our recent studies performed with trisubstituted cyclododecane derivatives have revealed greater conditional stability for $[\mathrm{Mn}(\mathrm{PCTA})]^{-}$than for $[\mathrm{Mn}(\mathrm{DOTA})]^{2-}$ (at $\mathrm{pH}=7.4) .{ }^{16}$ The kinetic inertness of [Mn(PCTA) $]^{-}$is sufficiently high to allow for further ligand modification, such as reduction of ligand denticity to allow the coordination of a water molecule to the metal ion. Truncating the parent PCTA ligand returns two regioisomeric ligands, the dissymmetric (3,6-disubstituted) and the symmetric (3,9-disubstituted) pyclen (pyclen = 3,6,9,15-tetraazabicyclo[9.3.1]pentadeca-1(15),11,13-triene) platforms, which can serve as alternatives to $1,4-\mathrm{DO}_{2} \mathrm{~A}$ for designing $\mathrm{Mn}(\mathrm{II})$ based relaxation agents (Chart 1 ). We have recently explored some features of certain symmetric (3,9-disubstituted) $\mathrm{PC}_{2} \mathrm{~A}$ derivatives. The attachment of an ethanolamine moiety, capable of protonation near to physiological $\mathrm{pH}$ in its $\mathrm{Mn}$ (II) complex, allowed us to obtain a pH-responsive $\mathrm{Mn}$ (II)-based smart CA (SCA) candidate (PC2AEA). ${ }^{21}$ Furthermore, "decorating" the 3,9-PC2A platform with biphenyl "anchor" returns the hexadentate PC2A-BP chelator, ${ }^{22}$ which binds HSA very efficiently, thereby allowing for the visualization of the vascular system by using low
CA doses. The aim of the current study is to synthesize both disubstituted regioisomers of the $\mathrm{PC}_{2} \mathrm{~A}$ ligand and characterize their complexes formed Mn(II) (thermodynamics, electrochemistry, dissociation and solvent exchange kinetics, relaxation properties and their structures), as well as the stability of complexes formed with the most abundant essential metal ions (Ca(II), $\mathrm{Mg}$ (II), $\mathrm{Cu}$ (II) and $\mathrm{Zn}(\mathrm{II})$ ). The SOD activity of the regioisomeric $\mathrm{Mn}$ (II) complexes was also accessed with the para-nitro blue tetrazolium chloride (NBT) assay and compared with the data determined for $\mathrm{Mn}(\mathrm{SOD}),\left[\mathrm{Mn}\left(15 \mathrm{aneN}_{5}\right)\right]^{2+}$ and $[\mathrm{Mn}(\mathrm{PCTA})]^{-}$.

Chart 1. Chemical structure of the ligands discussed in this work.

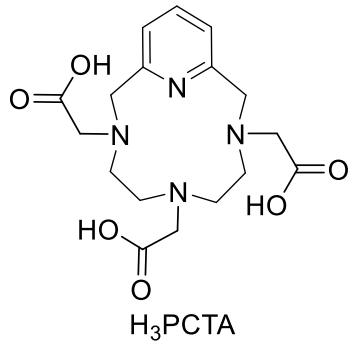<smiles>O=C(O)CN1CCNCCN(CC(=O)O)CCN(CC(=O)O)CC1</smiles>

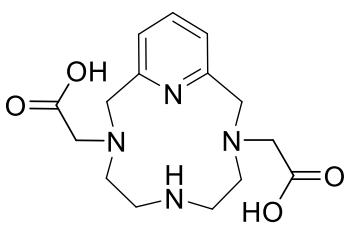

$\mathrm{H}_{2}$ 3,9-PC2A

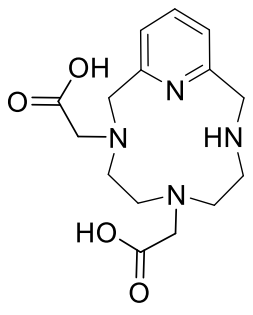

$\mathrm{H}_{2}$ 3,6-PC2A

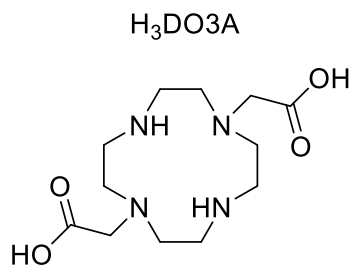

$\mathrm{H}_{2} 1,7-\mathrm{DO} 2 \mathrm{~A}$

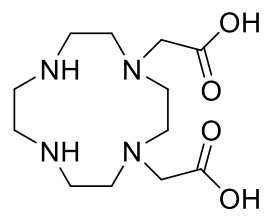

$\mathrm{H}_{2}$ 1,4-DO2A

\section{RESULTS AND DISCUSSION}

Syntheses of the ligands and complexes. The symmetric 3,9-PC2A ligand was synthesized by following published procedure reported by Kim et al. ${ }^{23}$ The given synthesis relies on the addition to the pyclen macrocycle of a stoichiometric amount of the formaldehyde - sodium bisulfite addition compound, while the $\mathrm{pH}$ of the reaction mixture is maintained at $\mathrm{pH}=8.55$ in order to protonate (i.e. protect) the N6 nitrogen atom situated trans to the pyridine unit. Although this method supposed to afford the intended (3,9-disubstituted) product in quantitative yield, in our hands $3-4 \%$ of the 3,6-disubstituted product was found in the reaction mixture. These products were converted to corresponding PC2As via substitution with $\mathrm{NaCN}$ followed by their hydrolysis in $6 \mathrm{M} \mathrm{HCl}$. The isomeric ligands were 
then separated/purified by preparative HPLC for the analytical work (analyses in supporting information, Fig. S1 to $\left.\mathrm{S}_{4}\right)$ ).

The synthesis of 3,6-PC2A was accomplished using a procedure affording solely the 3,6-disubstituted product (Scheme 1 details of synthesis of compounds $\mathbf{2}-\mathbf{9}$ and all analyses in supporting information, Scheme $\mathrm{S}_{1}$, Figures $\mathrm{S}_{5}$ to S28). The applied strategy relies on the regioselective protection of one of the secondary amines of the pyclen macrocycle, in order to introduce the two acetate arms on the remaining free secondary amines. To that aim, pyclenoxalate $\mathbf{1}$ was first prepared as described in the literature. ${ }^{24}$ Protection of compound $\mathbf{1}$ in the presence of 2-nitrobenzenesulfonyl chloride and $\mathrm{NaHCO}_{3}$ led to compound $\mathbf{2}$ in $89 \%$ yield. Deprotection of the latter with $4 \mathrm{M} \mathrm{HCl}$ under reflux followed by a precipitation in acetone afforded compound 5. Unfortunately, even after exchange of the counter-ion by an amberlite resin ( $\mathrm{OH}^{-}$form), the solubility of compound $\mathbf{5}$ was so low that it was not possible to perform its alkylation with two equivalents of methyl 2-bromoacetate, even under drastic conditions (DMF, reflux). We then envisioned the Fmoc protecting group as an alternative solution. Protection of compound $\mathbf{1}$ in the presence of Fmoc chloride was quantitative and deprotection of the oxalate group in acidic conditions under reflux led to compound $\mathbf{6}$. Alkylation of the latter with two equivalents of methyl 2bromoacetate was performed without base, but even in these conditions, partial removal of the Fmoc protecting group was observed, resulting in the formation of a mixture

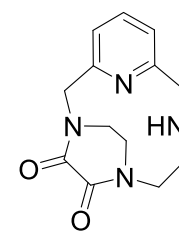

1

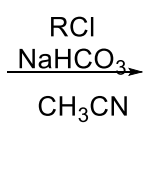

9

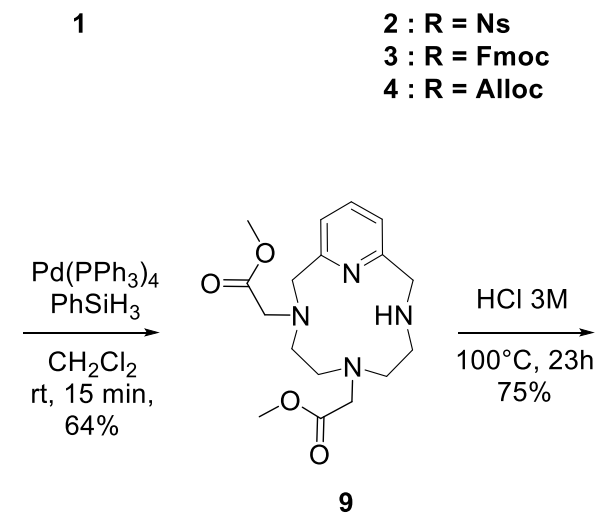

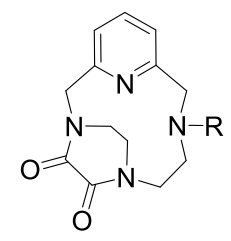

2: $\mathbf{R}=\mathbf{N s}$ 3: $\mathrm{R}=\mathrm{Fmoc}$ 4: $\mathbf{R}=$ Alloc
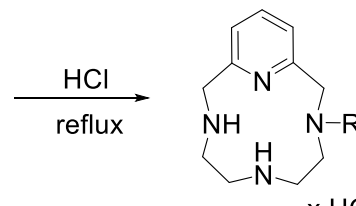

5: $R=$ Ns $(x=2)$ 6: $R=$ Fmoc $(x=2)$

$7: R=$ Alloc $(x=0)$

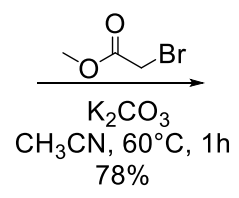

$78 \%$

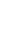

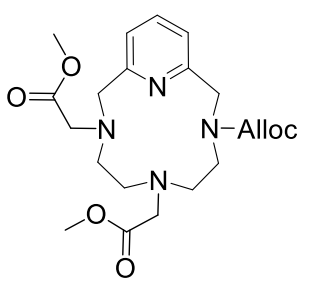

8
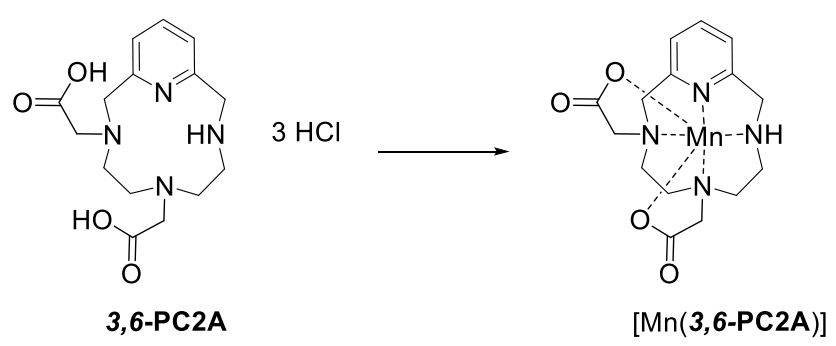

Scheme 1. Synthesis of the non-symmetric $\left[\mathrm{Mn}\left(3,6-\mathrm{PC}_{2} \mathrm{~A}\right)\right]$ complex.

\footnotetext{
Table 1. Protonation constants of the 3,9-PC2A, 3,6-PC2A, 1,7-DO2A, 1,4-DO2A PCTA and $\mathrm{DO}_{3} \mathrm{~A}$ ligands $\mathrm{T}=25^{\circ} \mathrm{C}$ and $I=0.15 \mathrm{M} \mathrm{NaCl})$.
} 


\begin{tabular}{|c|c|c|c|c|c|c|}
\hline & $3,9-\mathrm{PC}_{2} \mathrm{~A}$ & $3,6-\mathrm{PC}_{2} \mathrm{~A}$ & $1,7-\mathrm{DO}_{2} \mathrm{~A}^{\mathrm{c}}$ & $1,4-\mathrm{DO}_{2} \mathrm{~A}^{\mathrm{c}}$ & PCTA & $\mathrm{DO}_{3} \mathrm{~A}^{\mathrm{d}, \mathrm{f}}$ \\
\hline $\log K_{1}{ }^{\mathrm{H}}$ & $12.25(4) / 12.50^{a}$ & $10.72(1) / 10.31(1)^{b}$ & 11.69 & 11.44 & $9.97^{d} / 11.36^{\mathrm{e}}$ & 10.07 \\
\hline $\log K_{2}{ }^{\mathrm{H}}$ & $5.97(2) / 5.75^{a}$ & $8.37(2) / 8.59(2)^{b}$ & 9.75 & $9 \cdot 51$ & $6.73^{d} / 7.35^{\mathrm{e}}$ & 9.83 \\
\hline $\log K_{3}{ }^{\mathrm{H}}$ & $3.47(4) / 3.28^{a}$ & $3.81(2) / 3.92(3)^{b}$ & 3.97 & 4.14 & $3.22^{d} / 3.83^{e}$ & 4.43 \\
\hline $\log K_{4}{ }^{\mathrm{H}}$ & $1.99(3) / 2.38^{a}$ & $1.26(2) / 1.56(3)^{b}$ & 2.68 & 1.55 & $1.4 \mathrm{O}^{d} / 2.12^{\mathrm{e}}$ & 4.11 \\
\hline$\sum_{i=1}^{2} \log K_{i}^{H}$ & $18.22 / 18.25^{a}$ & $19.09 / 18.90$ & 21.44 & 20.95 & $16.70^{d} / 18.71^{\mathrm{e}}$ & 19.90 \\
\hline
\end{tabular}

${ }^{a}$ Data in o.1 M KCl from Ref. 23. ${ }^{b}$ Determined by using $1.0 \mathrm{M} \mathrm{NaCl}$ ionic background. ${ }^{c}$ Data from Ref. $18 .{ }^{d}$ Data from Ref. 16. ${ }^{e}$ Data in $1.0 \mathrm{M} \mathrm{KCl}$ at $25^{\circ} \mathrm{C}$ from Ref. $29 .{ }^{f}$ An additional protonation with $\log K_{5}^{\mathrm{H}}=1.88$ was also detected.

Equilibrium studies. The protonation constants of the two pyclen derivatives investigated in this work have been determined by $\mathrm{pH}$-potentiometry using $0.15 \mathrm{M}$ as well as 1.o $\mathrm{M} \mathrm{NaCl}$, since the determination of $\mathrm{Cu}(\mathrm{II})$ stabilities required higher ionic strengths. The protonation constants (see experimental section for details) of the ligands and their standard deviations are listed in Table 1, along with the corresponding values determined for $1,7-\mathrm{DO}_{2} \mathrm{~A}, 1,4^{-}$ $\mathrm{DO}_{2} \mathrm{~A}$ and PCTA.

The protonation sequence of PCTA and its derivatives differs from that of DOTA and other cyclen-based ligands owing to the non-symmetric nature of the pyclen macrocycle. ${ }^{27}$ The first protonation of the PCTA occurs at the nitrogen situated in trans to the pyridine nitrogen $\left(\mathrm{N}^{6}\right)$ of the pyclen macrocycle, while the second protonation occurs at the cis- nitrogen ( $\mathrm{N}^{3}$ or $\left.\mathrm{N}^{9}\right)$, forcing the first proton to rearrange to the second cis- nitrogen atom to alleviate electrostatic repulsion. In agreement with this sequence, the highest protonation constant of 3,9-PC2A $\left(\log K_{1}^{\mathrm{H}}=12.5\right)$ can be assigned to the protonation of the $\mathrm{N} 6$ nitrogen atom opposite to the pyridine ring, which is in agreement with the ${ }^{1} \mathrm{H}-\mathrm{NMR}$ titration reported by Kim et al. ${ }^{23}$ The same authors proposed that the second protonation constant (log $\left.K_{2}{ }^{\mathrm{H}}=5.75\right)$ corresponded to the pyridine nitrogen atom. However, the ${ }^{1} \mathrm{H}-\mathrm{NMR}$ titration was performed in a relatively narrow $\mathrm{pH}$ range (the lowest $\mathrm{pH}$ at which the ${ }^{1} \mathrm{H}$-NMR spectrum was recorded was around $\mathrm{pH}=7$ ). Moreover, if one assumes similar protonation sequence for the non-symmetric ligand, the second protonation constant of $\log K_{2}{ }^{\mathrm{H}}=8.37$ would be too high for the protonation of a pyridine nitrogen atom. Therefore, we feel that the protonation sequence of the PCTA proposed by S. Aime et al. holds also for the $\mathrm{PC}_{2} \mathrm{~A}$ isomeric ligands. A similar protonation sequence was proposed by Drahos et al. for 6-PC $1 \mathrm{~A}$ on the basis of ${ }^{1} \mathrm{H}$ NMR experiments. ${ }^{28}$ The $\log K_{1}^{\mathrm{H}}$ value of 3,9-PC2A decreases significantly upon functionalization of the secondary $\mathrm{NH}$ group with biphenyl (BP) or ethylamine (EA) substituents $\left(\log K_{1}^{\mathrm{H}}=10.45\right.$ and 11.34, respectively, vs. 12.25 in 3,9-PC2A). ${ }^{21,22}$

The isomeric $\mathrm{PC}_{2} \mathrm{~A}$ ligands were found to be less basic than the $\mathrm{DO}_{2} \mathrm{~A}$ derivatives, as judged by the $\Sigma \log K_{i}^{\mathrm{H}}$ values (Table 1). However, the parent PCTA ligand appears to be even less basic, which can be related in part to the formation of a relatively stable complex with the $\mathrm{Na}^{+}$ions present at high concentration in the sample (originating for the ionic strength). Indeed, the protonation constants of
PCTA determined in $1.0 \mathrm{M} \mathrm{KCl}$ are considerably higher than those determined in $0.15 \mathrm{M} \mathrm{NaCl},{ }^{16,29}$ while an intermediate $\log K_{1}{ }^{\mathrm{H}}$ value of 10.90 was determined using $I=0.1$ $\mathrm{M} \mathrm{Me}_{4} \mathrm{NO}_{3} .^{30}$ The increasing negative charge of the ligands (i.e. increasing number of carboxylate groups capable of binding $\mathrm{Na}^{+}$ions) is expected to enhance the stability of the $\mathrm{Na}^{+}$complex, as it was also evidenced for cyclen-based chelators. ${ }^{31,32}$ However, the protonation constants of $1,4^{-}$ and $1,7-\mathrm{DO}_{2} \mathrm{~A}$ derivatives determined using $0.15 \mathrm{M} \mathrm{NaCl}$ and $0.1 \mathrm{M} \mathrm{Me}_{4} \mathrm{NCl}$ electrolytes are nearly identical, 33 indicating the absence of stable $\mathrm{Na}^{+}$complex formation for these disubstituted derivatives. The data available in the literature for 3,9-PC2A are also confirming our hypothesis, ${ }^{23}$ since the values determined with the use of $0.1 \mathrm{M} \mathrm{KCl}$ and those reported here in $0.15 \mathrm{M} \mathrm{NaCl}$ do not differ considerably (the difference in the first protonation constant is only ca. $0.2 \log$ units, Table 1 ).

The stability and protonation constants of the M(II) complexes ( $\mathrm{M}=\mathrm{Ca}, \mathrm{Mg}, \mathrm{Mn}, \mathrm{Cu}$ and $\mathrm{Zn}$ ) formed with 3,9-PC2A and 3,6-PC2A were determined by $\mathrm{pH}$-potentiometric titrations (Table 2). The equilibrium model used for the fitting of the $\mathrm{pH}$-potentiometric data involving the $\mathrm{Mn}$ (II) ion was confirmed with $\mathrm{pH}$ dependent ${ }^{1} \mathrm{H}$-relaxometric titration experiments (Figure 1). A comparison of the $\mathrm{pH}$-relaxivity profiles with the species distribution curves, calculated by using the stability constants obtained by $\mathrm{pH}-\mathrm{po}-$ tentiometric titration, confirms that the equilibrium model applied for the data refinement is correct. The $\left[\mathrm{Mn}\left(\mathbf{3}, \mathbf{9}-\mathrm{PC}_{2} \mathrm{~A}\right)\right]$ and $\left[\mathrm{Mn}\left(\mathbf{3}, \mathbf{6}-\mathrm{PC}_{2} \mathrm{~A}\right)\right]$ complexes exhibit constant relaxivity $\left(2.91\right.$ and $2.72 \mathrm{mM}^{-1} \mathrm{~s}^{-1}$ respectively at $\left.0.49 \mathrm{~T}, 25^{\circ} \mathrm{C}\right)$ in a wide $\mathrm{pH}$ range $(4.5-9.5$, the relaxivity of the complexes determined at 0.49 and $1.41 \mathrm{~T}$ at $25^{\circ} \mathrm{C}$ are included in the Supporting Information Figure $\mathrm{S}_{30} \mathrm{O} \mathrm{S}_{33}$ ). These results are characteristic of macrocyclic Mn(II) complexes with one coordinated water molecule $(q=1)$ in their inner coordination sphere (i.e. [Mn $\left.\left(1,4-\mathrm{DO}_{2} \mathrm{~A}\right)\right]$ and $\left.\left[\mathrm{Mn}\left(6-\mathrm{PC}_{1} \mathrm{~A}\right)\right]^{+}\right), 4,28$ and they are higher than the relaxivity of complexes with $q=0$ (typically $1.4^{-1} .6 \mathrm{mM}^{-1} \mathrm{~s}^{-1}$ as observed for $\left[\mathrm{Mn}\left(\mathrm{DO}_{3} \mathrm{~A}\right)\right]^{-}$and $[\mathrm{Mn}(\mathrm{PCTA})]^{-} .{ }^{4,16}$ Lowering the $\mathrm{pH}$ below $\mathrm{pH}=4.5$ results in a sharp relaxivity increase, reaching $r_{1 \mathrm{p}}$ values of 8.12 and $6.28 \mathrm{mM}^{-1} \mathrm{~s}^{-1}$ (at 0.49 and $1.41 \mathrm{~T}$, respectively) near $\mathrm{pH}=2.50$ and 1.80 for the complexes formed with 3,6-PC2 $\mathrm{A}$ and 3,9-PC2A ligands. The increase in relaxivity is associated to the protonation of the complex followed by dissociation at low $\mathrm{pH}$, reaching $r_{1 \mathrm{p}}$ values characteristic of the $\left[\mathrm{Mn}\left(\mathrm{H}_{2} \mathrm{O}\right)_{6}\right]^{2+}$ complex. ${ }^{34}$ Half of 
$\mathrm{Mn}(\mathrm{II})$ ions are present as the hexaaqua form at $\mathrm{pH} 2.5$ in case of the 3,9-PC2A system and at $\mathrm{pH} \sim 3.5$ with the 3,6$\mathrm{PC}_{2} \mathrm{~A}$ ligand, which suggests a significantly higher stability for the $\left[\mathrm{Mn}\left(3,9-\mathrm{PC}_{2} \mathrm{~A}\right)\right]$ complex.

The equilibrium can be described by considering only the formation of $[\mathrm{M}(\mathrm{L})]$ and monoprotonated $[\mathrm{M}(\mathrm{HL})]$ complexes for both systems (3,9-PC2A and 3,6-PC2A) involving all metal ions (Table 2 ). The data listed in the Table 2 show that the symmetric 3,9-PC2A forms more stable complexes with cations possessing high coordination numbers (including $\mathrm{Mn}(\mathrm{II})$ ) than the non-symmetric 3,6-PC2A, while for $\mathrm{Cu}(\mathrm{II})$ and $\mathrm{Zn}$ (II) the trend seems to be reversed. In fact, the stability of the Mn(II) complex formed with 3,9PC2A appears to be slightly higher than that of the complex formed with PCTA $\left(\log K_{\mathrm{MnL}}=17.09\right.$ vs. 16.83 , respectively). This can be rationalized in terms of the increased basicity of the 3,9-PC2A ligand upon removing one of the acetate pendant arms. However, the high basicity of the 3,9-PC2A ligand triggers a notable decrease of the conditional stability when the basicity of the ligands is taken into account. This can be visualized by comparing the conditional equilibrium data (i.e. pMn values of the complexes) at specific conditions. When comparing the calculated $\mathrm{pMn}$ values $\left(\mathrm{pMn}=-\log [\mathrm{Mn}]_{\text {free }}\right.$ of the complexes at $\mathrm{pH}=$ 7.4 and using $10 \mu \mathrm{M}$ ligand and $\mathrm{Mn}$ (II) ion concentration) the affinity of the 3,9-PC2A ligand towards $\mathrm{Mn}$ (II) is lower than that of the PCTA (pMn = 8.64 vs. 9.74). Nevertheless, 3,9-PC2A appears to be a good platform for the complexation of $\mathrm{Mn}(\mathrm{II})$ as the pMn value is just slightly lower than that of the Mn(DOTA) complex calculated under identical conditions $(\mathrm{pMn}=9.02) .{ }^{16}$ A comparison with the data of the corresponding $\mathrm{DO}_{2} \mathrm{~A}$ ligands shows the benefit of incorporating the pyridine moiety into the ligand backbone.

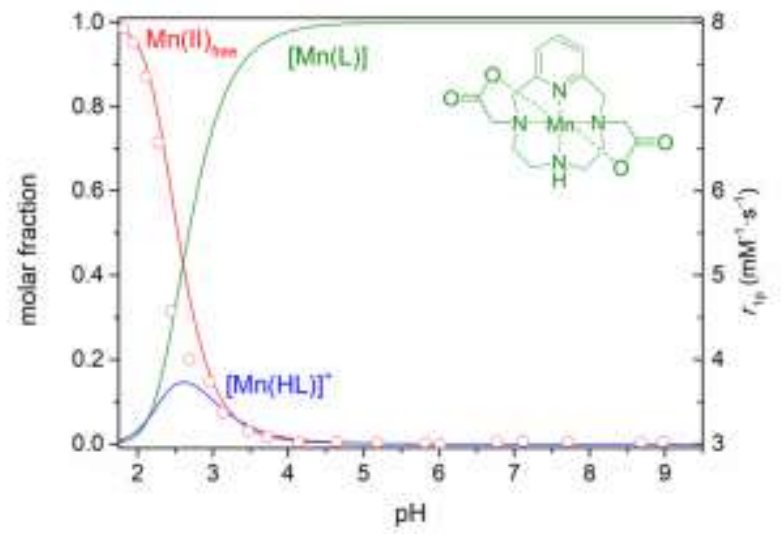

The stability constants of the $[\mathrm{Mn}(3,6-\mathrm{PC} 2 \mathrm{~A})]$ and $\left[\mathrm{Mn}\left(1,4^{-}\right.\right.$ $\left.\left.\mathrm{DO}_{2} \mathrm{~A}\right)\right]$ complexes are nearly identical $\left(\log K_{\mathrm{MnL}}=15.53\right.$ and 15.68, respectively). However the calculated $\mathrm{pMn}$ values show one-unit difference, whereas for the $[\mathrm{Mn}(3,9-\mathrm{PC} \mathbf{A})]$ and $\left[\mathrm{Mn}\left(1,7-\mathrm{DO}_{2} \mathrm{~A}\right)\right]$ complexes the benefit is even more pronounced (2.5 log units in terms of stability and two orders of magnitude in terms of the conditional stability).

The complex formation for the $\mathrm{Cu}$ (II) systems with both 3,6-PC2A and 3,9-PC2A ligands is complete below $\mathrm{pH}$ 1.7, which is the lower limit for $\mathrm{pH}$-potentiometry. Therefore, the stability constants of the $\mathrm{Cu}$ (II) complexes were determined by simultaneous fitting of $\mathrm{pH}$-potentiometric data collected in the $\mathrm{pH}$ range of $\mathrm{pH}=1.72-11.85$ and $\mathrm{UV}$-vis spectrophotometric titration data using batch samples with the $\left[\mathrm{H}^{+}\right]$concentration ranging from $0.011-0.913 \mathrm{M}$ and 0.011 - 1.020 M, respectively (Figure S34, Supporting Information). The molar absorptivities of $\mathrm{Cu}(\mathrm{II})$ and its corresponding complexes were determined independently, while those of the protonated species were fitted during the data refinement. The stability constants of the $\mathrm{Cu}$ (II) complexes (Table 2) are very similar to those determined previously for isomeric $\mathrm{DO}_{2} \mathrm{~A}$ complexes and they are seemingly higher than the value characterizing the $[\mathrm{Cu}(\mathrm{PCTA})]^{-}$complex. However our recent experimental evidences suggest that the stability of the $[\mathrm{Cu}(\mathrm{PCTA})]^{-}$complex was underestimated in our former study. ${ }^{29}$ The UV-Vis spectra of the protonated complex collected up to $1 \mathrm{M}$ acid concentration did not indicate any measurable dissociation of the complex, as evidenced by identical spectra obtained in the acid concentration range of 0.1 - 1.0 M. One can estimate the lower limit of the stability constant of the $[\mathrm{Cu}(\mathrm{PCTA})]^{-}$complex as $\log K_{\mathrm{CuL}}$ $(\min )=24$.

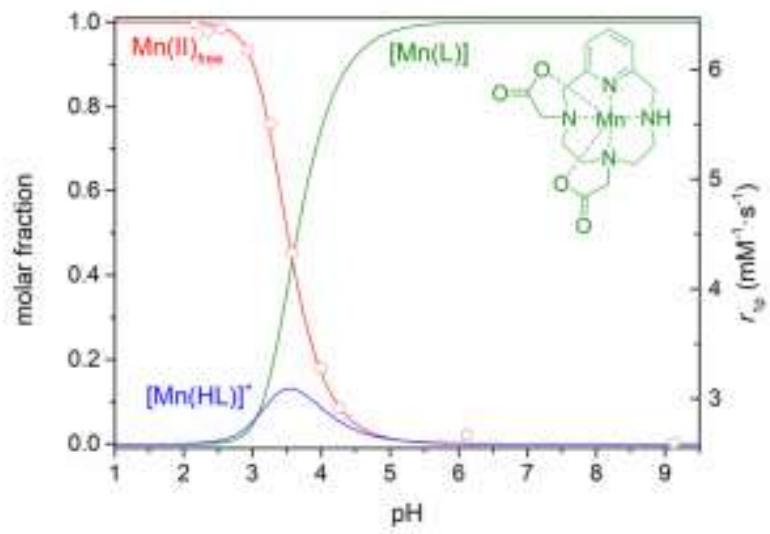

Figure 1. Species distribution diagram of the $\mathrm{Mn}(\mathrm{II})-\mathrm{L}-\mathrm{H}^{+}$systems $([\mathrm{Mn}(\mathrm{II})]=[\mathrm{L}]=\mathbf{2 . 0 4} \mathrm{mM}$, solid lines, $\mathrm{L}=$ 3,9- or 3,6$\left.\mathbf{P C}_{2} \mathbf{A}\right)$ and the normalized $r_{1 \mathrm{p}}$ relaxivity values obtained as function of $\mathrm{pH}$ at $0.49 \mathrm{~T}(3,9-\mathbf{P C} \mathbf{A})$ or 1.41 $(3,6-\mathbf{P C} \mathbf{A}$, red dots, $\mathrm{T}=25^{\circ} \mathrm{C}$ and $\left.I=0.15 \mathrm{M} \mathrm{NaCl}\right)$.

Table 2. Stability and protonation constants of the $\mathrm{Mg}(\mathrm{II}), \mathrm{Ca}(\mathrm{II}), \mathrm{Mn}(\mathrm{II}), \mathrm{Cu}(\mathrm{II})$ and $\mathrm{Zn}(\mathrm{II})$ complexes of 3,9-PC2A, 3,6-PC2A, 1,7-DO2A, 1,4-DO2A, PCTA and $\mathrm{DO}_{3} \mathrm{~A}$ ligands $\left(\mathrm{T}=25^{\circ} \mathrm{C}\right.$ and $\left.\mathrm{I}=0.15 \mathrm{M} \mathrm{NaCl}\right)$.

$\begin{array}{ccccccc} & 3,9-\mathrm{PC}_{2} \mathrm{~A} & \mathbf{3 , 6}-\mathrm{PC}_{2} \mathrm{~A} & \mathbf{1 , 7}-\mathrm{DO}_{2} \mathrm{~A}^{d} & \mathbf{1 , 4}-\mathrm{DO}_{2} \mathrm{~A}^{d} & \mathrm{PCTA}^{e} & \mathrm{DO}_{3} \mathrm{~A}^{\mathrm{f}} \\ \log K_{\mathrm{MgL}} & 9.84(8) / 8.40^{b} & 8.11(1) & - & - & 12.35 & 11.64\end{array}$




\begin{tabular}{lcccccc}
$\log K_{\mathrm{MgL}}{ }^{\mathrm{H}}$ & $5.91(10)$ & $5.87(9)$ & - & - & 3.82 & - \\
$\log K_{\mathrm{CaL}}$ & $9.92(5) / 10.0^{b}$ & $9.57(1)$ & 8.86 & 8.62 & 12.72 & 12.57 \\
$\log K_{\mathrm{CaL}}{ }^{\mathrm{H}}$ & $5.08(6)$ & $5.27(9)$ & - & - & 3.79 & 4.60 \\
$\log K_{\mathrm{MnL}}$ & $17.09(2)$ & $15.53(1)$ & 14.64 & 15.68 & $16.83 / 16.64$ & $16.55^{\mathrm{g}} / 19.43$ \\
$\log K_{\mathrm{MnL}}{ }^{\mathrm{H}}$ & $2.14(2)$ & $3.06(4)$ & 4.40 & 4.15 & 1.96 & $4.26^{\mathrm{g}} / 3.55$ \\
$\mathrm{pMn}^{a}$ & 8.64 & 8.09 & 6.52 & 7.27 & 9.74 & 8.66 \\
$\log K_{\mathrm{CuL}}$ & $23.58(4)^{c}$ & $24.09(3)^{\mathrm{c}}$ & 24.24 & 24.43 & 18.79 & 25.75 \\
$\log K_{\mathrm{CuL}}{ }^{\mathrm{H}}$ & $2.12(8)^{\mathrm{c}}$ & $2.37(3)^{\mathrm{c}}$ & 3.06 & 2.95 & 20.48 & $3.65^{\mathrm{j}}$ \\
$\log K_{\mathrm{ZnL}}$ & $19.49(8)$ & $20.37(1)$ & 18.86 & 18.03 & 3.10 & 19.43 \\
$\log K_{\mathrm{ZnL}}{ }^{\mathrm{H}}$ & $2.74(4)$ & $2.36(1)$ & 4.23 & 3.58 & - & 3.37 \\
$\log K_{\mathrm{ZnHL}}{ }^{\mathrm{H}}$ & - & - & 1.78 & 1.65 & - \\
\hline
\end{tabular}

${ }^{a}$ Calculated using $c_{\mathrm{L}}=\mathrm{c}_{\mathrm{Mn}(\mathrm{II})}=1 \times 10^{-5} \mathrm{M}$ at $\mathrm{pH}=7.4 \cdot{ }^{b}$ Data in $0.1 \mathrm{M} \mathrm{KCl}$ from Ref. $23 .{ }^{c} I=1.0 \mathrm{M} \mathrm{NaCl}$; determined by simultaneous fitting of the $\mathrm{pH}$-potentiometric and UV-vis data. ${ }^{d}$ Values in $0.1 \mathrm{M} \mathrm{KCl}$ from Ref. 19 for $\mathrm{Ca}$, $\mathrm{Cu}$ and Zn; Values in $0.15 \mathrm{M} \mathrm{NaCl}$ from Ref. 18 for Mn. ${ }^{e}$ Values in $I=1.0 \mathrm{M} \mathrm{KCl}$ from Ref. 29, except for Mn (o.15 M NaCl, Ref. 16). $f$. Data in 0.1 $\mathrm{M} \mathrm{KCl}$ from Ref. 31. ${ }^{g}$ Data in $0.15 \mathrm{M} \mathrm{NaCl}$ from Ref. $16 .{ }^{j}$ The formation of a diprotonated complex with $\log K_{\mathrm{MH} 2 \mathrm{~L}}=1.69$ was also reported.
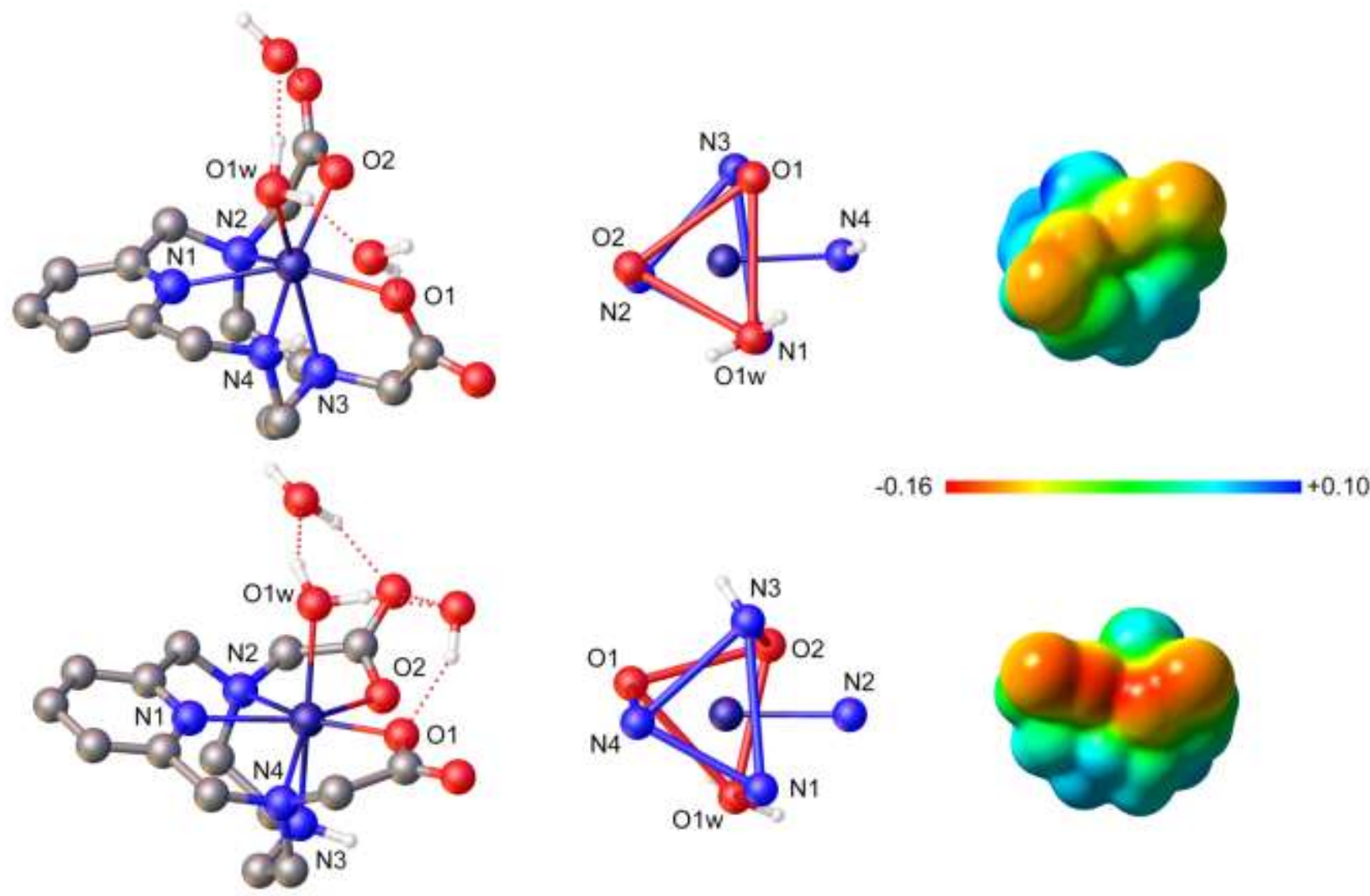

Figure 2. Geometries of the $\left[\mathrm{Mn}(3,6-\mathbf{P C} \mathbf{2} \mathbf{A})\left(\mathrm{H}_{2} \mathrm{O}\right)\right] \cdot 2 \mathrm{H}_{2} \mathrm{O}$ (top) and $\left[\mathrm{Mn}(3,9-\mathbf{P C} \mathbf{2} \mathbf{A})\left(\mathrm{H}_{2} \mathrm{O}\right)\right] \cdot 2 \mathrm{H}_{2} \mathrm{O}$ (bottom) systems obtained with DFT calculations at the M11/Def2-TZVPP level (left), the corresponding coordination polyhedral (center) and the electrostatic potential (a. u.) calculated on a isodensity surface defined by o.oo1 of the electron density (right, views along the Mn-Ni axes).

DFT calculations. In order to understand the differences in the stability of $\mathrm{Mn}$ (II) complexes formed with 3,9$\mathbf{P C}_{2} \mathrm{~A}$ and 3,6-PC2A, we turned our attention to DFT calculations. On the basis of our previous experience, we performed calculations on the $\left[\mathrm{Mn}(\mathrm{L})\left(\mathrm{H}_{2} \mathrm{O}\right)\right] \cdot 2 \mathrm{H}_{2} \mathrm{O}$ systems $(\mathrm{L}$
= 3,6-PC2A or 3,9-PC2A), which include two explicit second-sphere water molecules to improve the accuracy of the calculated $\mathrm{Mn}-\mathrm{O}_{\text {water }}$ distances and ${ }^{17} \mathrm{O}$ hyperfine coupling constants. 35 The optimized geometries are presented in Figure 2 (the Cartesian coordinates of the complexes are reported in the Supporting Information, Table S1 and S2), 
while the calculated distances of the metal coordination environments are given in Table $\mathrm{S}_{3}$ (Supporting Information). Our calculations provide seven-coordinated $\mathrm{Mn}$ (II) for both complexes, where the coordination polyhedra can be described as a capped trigonal prisms.

The shortest bond distances of the metal coordination environment involve the $\mathrm{O}$ atoms of carboxylate groups, as would be expected due to the hard Lewis acid character of $\mathrm{Mn}(\mathrm{II})$. Concerning the Mn-N bonds, the strongest coordination in the 3,6-PC2A complex is provided by the $\mathrm{N}$ atom of the pyridine group $\left(\mathrm{Mn}-\mathrm{N}_{\mathbf{1}}=\mathbf{2 . 3 4 2} \AA\right.$ ), as also observed in the X-ray crystal structures of $\mathrm{Mn}(\mathrm{II})$ complexes formed with pyclen derivatives [Mn $\left.\left(6-\mathrm{PC}_{1} \mathrm{~A}\right) \mathrm{Cl}\right](2.199 \AA)^{28}$ and $\left[\mathrm{Mn}\left(\mathrm{PCTA}-(\mathrm{OEt})_{3}\right)\right]^{2+}\left(2.16_{5} \AA{ }^{\circ}\right){ }^{36}$ In these structures, the nitrogen atom of the macrocycle located trans to the pyridine nitrogen coordinates rather weakly to the $\mathrm{Mn}(\mathrm{II})$ ion, as evidenced by rather long $\mathrm{Mn}-\mathrm{N}$ bond lengths (corresponding bond lengths are 2.349 $\AA$ and 2.431 $\AA$ in [Mn(6$\left.\left.\mathrm{PC}_{1} \mathrm{~A}\right)\right]^{+}$and $\left[\mathrm{Mn}\left(\mathrm{PCTA}-(\mathrm{OEt})_{3}\right)\right]^{2+}$ complexes, respectively. Similarly, the calculated structure of the 3,6-PC2A complex presents a relatively long $\mathrm{Mn}-\mathrm{N}_{3}$ distance (2.362 $\AA$ ). The absence of a carboxylate pendant in trans to the pyridyl $\mathrm{N}$

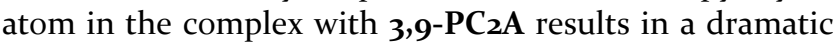
shortening of the Mn-N3 bond length to $2.289 \AA$, while the distance to the pyridyl $\mathrm{N}$ atom is also shortened significantly to $2.314 \AA$. Based on these bond lengths, it appears that the presence of a carboxylate group in trans to the pyridyl $\mathrm{N}$ atom hinders the coordination of the amine $\mathrm{N}$ atom at position 6 . The absence of a pendant arm at this position, such as in the complex with 3,9-PC2A, likely releases steric strain, allowing for a more tight coordination of the $\mathrm{N}$ atoms at positions 1 and $6\left(\mathrm{~N}_{1}\right.$ and $\mathrm{N}_{3}$ in Figure 2$)$.

Dissociation of the Mn(II) complexes. Metal chelates used in medical diagnosis and therapy must be kinetically inert so they do not dissociate to release free metal ion and ligand during the time they remain in vivo. Although $\mathrm{Mn}(\mathrm{II})$ is an essential metal ion, prolonged exposure to Mn(II) causes clinical signs and symptoms resembling, but not identical, to Parkinson's disease. Thus, the kinetics of decomplexation is a critical issue that must be considered to develop $\mathrm{Mn}$ (II)-based CA candidates. Therefore, the dissociation kinetics of the $\left[\mathrm{Mn}\left(3,6-P_{2} A\right)\right]$ and $[\mathrm{Mn}(3,9-$ PC2A)] complexes were studied by various methods to evaluate their inertness.
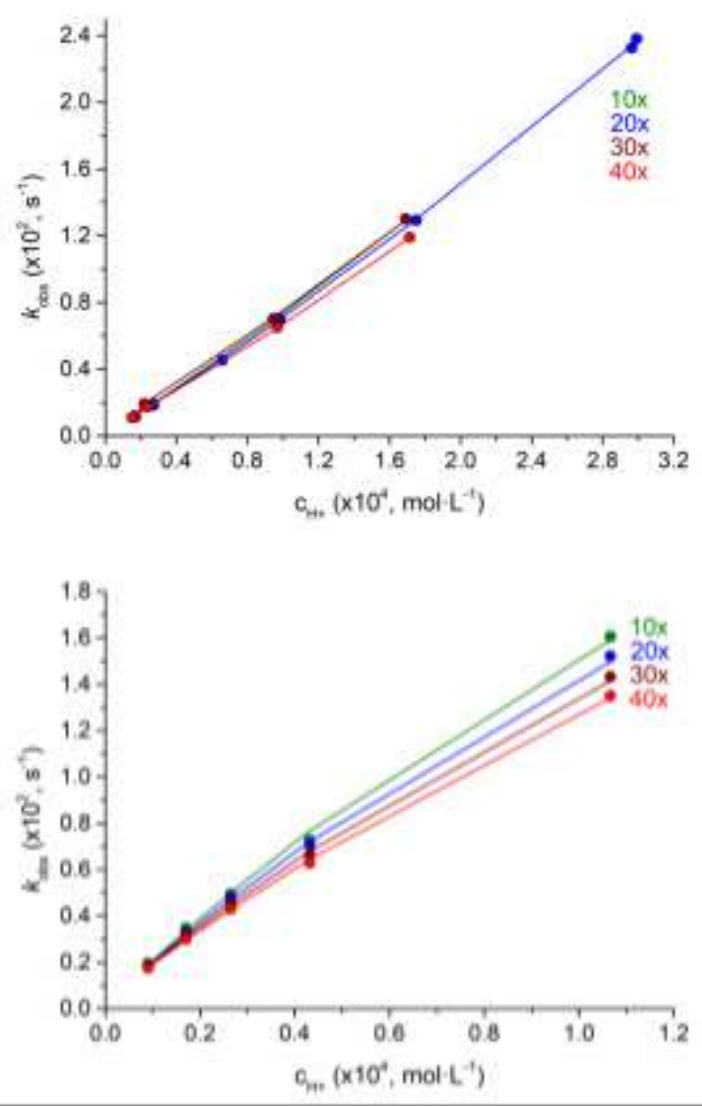

Figure 3. Dissociation rates ( $\left.k_{\mathrm{obs}}\right)$ of the $\mathrm{Mn}(\mathrm{II})$ complexes formed with 3,6- (top) and 3,9-PC2A (bottom) obtained in the presence of excess $\mathrm{Cu}$ (II) $(10,20,30$ and 40 equiv.) and plotted as a function of $\mathrm{H}^{+}$ion concentration ( $I$ $=0.15 \mathrm{M} \mathrm{NaCl}, \mathrm{T}=25^{\circ} \mathrm{C}$ ).

Metal exchange reactions occurring with $\mathrm{Zn}(\mathrm{II})$ at $\mathrm{pH}=$ 6.o. First, we evaluated the rate of the metal exchange reaction occurring with $\mathrm{Zn}$ (II) under the conditions proposed by Caravan and coworkers (metal exchange reaction initiated by 25 equiv. of $\mathrm{Zn}(\mathrm{II})$ at $\mathrm{pH}=6.0$, set by $50 \mathrm{mM}$ MES buffer), using $T_{2}$ relaxometry at $37^{\circ} \mathrm{C} .{ }^{10}$ Because $\mathrm{Zn}$ (II) forms more stable complexes than $\mathrm{Mn}$ (II), it can be used to trigger the dissociation. Owing to the high $r_{2 \mathrm{p}}$ relaxivity of the $\mathrm{Mn}(\mathrm{II})$ ion released as a result of dissociation (64.3 and $54.2 \mathrm{mM}^{-1} \mathrm{~s}^{-1}$ at $1.41 \mathrm{~T}$ and 25 and $37{ }^{\circ} \mathrm{C}$, respectively), measuring relaxation rates as function of time is a very sensitive method to probe the inertness of $\mathrm{Mn}$ (II) complexes. The pseudo-first-order rate constants determined for the dissociation of $\left[\mathrm{Mn}\left(3,6-\mathrm{PC}_{2} \mathrm{~A}\right)\right]$ and $\left[\mathrm{Mn}\left(3,9-\mathrm{PC}_{2} \mathrm{~A}\right)\right] \mathrm{com}-$ plexes are $(3.28 \pm 0.03) \times 10^{-4}$ and $(5.43 \pm 0.04) \times 10^{-4} \mathrm{~s}^{-1}$, respectively (Figures S35, Supporting Information). These values are similar than that reported previously for $\left[\mathrm{Mn}\left(\mathrm{PyC}_{3} \mathrm{~A}\right)\right]$ $\left.(6.76 \pm 0.04) \times 10^{-4} \mathrm{~s}^{-1}\right),{ }^{10}$ which was proposed as an alternative to Gd(III)-based CAs. These data indicate that the isomeric ligand form $\mathrm{Mn}$ (II) complexes endowed with different inertness, with the $[\mathrm{Mn}(\mathbf{3}, \mathbf{6}-\mathbf{P C} \mathbf{A})]$ complex dissociat- 
ing more slowly. However, the differences are less pronounced than those observed recently for the Gd(III) complexes formed with pyclen mono and dipicolinates. ${ }^{37}$

Metal exchange reactions occurring with $\mathrm{Cu}(\mathrm{II})$. We have performed a detailed dissociation kinetics study by evaluating the rate constants of metal exchange reactions occurring with the $\mathrm{Cu}(\mathrm{II})$ ion in the $\mathrm{pH}$-range of $3.55-4.75$ (3,6-PC2A) and 3.97-5.02 (3,9-PC2A). As it can be seen in Figure 3 , the $k_{\text {obs }}$ rate constants increase with increasing $\mathrm{H}^{+}$ ion concentration, showing a saturation-like behavior for the $\left[\mathrm{Mn}\left(3,9-\mathbf{P C}_{2} \mathrm{~A}\right)\right]$ complex, and a second order dependence on $\mathrm{H}^{+}$ion concentration for $\left[\mathrm{Mn}\left(3,6-\mathrm{PC}_{2} \mathrm{~A}\right)\right]$. However, the $k_{\text {obs }}$ values decrease with increasing $\mathrm{Cu}(\mathrm{II})$ ion concentration for both complexes (the effect of the metal ion is more pronounced for $\left.\left[\mathrm{Mn}\left(3,9-\mathbf{P C}_{2} \mathrm{~A}\right)\right]\right)$. These data indicate that the $\mathrm{Mn}(\mathrm{II})$ complexes dissociate spontaneously and following the acid assisted pathway. However, in the presence of large excess of $\mathrm{Cu}(\mathrm{II})$ the formation of the heterodinuclear $[\mathrm{Mn}(\mathrm{L}) \mathrm{Cu}]$ complex decelerates the reactions, presumably by reducing the concentration of kinetically more reactive protonated form(s) of the complexes. Taking into account the possible reaction pathways, the rate of dissociation of the $\mathrm{Mn}$ (II) complexes can be expressed as in Eqn (1):

$$
\begin{aligned}
& -\frac{d[\mathrm{Mn}(\mathrm{L})]}{d t}=k_{o b s}[\mathrm{Mn}(\mathrm{L})]_{t}=k_{0}[\mathrm{Mn}(\mathrm{L})]+k_{\mathrm{H}}[\mathrm{Mn}(\mathrm{HL})]+ \\
& k_{\mathrm{H}}^{\mathrm{H}}\left[\mathrm{Mn}\left(\mathrm{H}_{2} \mathrm{~L}\right)\right]+k_{\mathrm{M}}[\mathrm{Mn}(\mathrm{L}) \mathrm{Cu}]
\end{aligned}
$$

where $k_{\text {obs }}$ is a pseudo-first-order rate constant, $[\mathrm{Mn}(\mathrm{L})]_{\mathrm{t}}$ is the total concentration of the $\mathrm{Mn}$ (II) chelates, $k_{\mathrm{o}}$ is the rate constant characterizing the spontaneous dissociation, $k_{\mathrm{H}}$ and $k_{\mathrm{H}}{ }^{\mathrm{H}}$ are the rate constants corresponding to the acidassisted dissociation, and $k_{\mathrm{M}}$ is the rate constant characterizing the metal-assisted dissociation pathway. Taking into account the concentration of various complexes $(\mathrm{Mn}(\mathrm{L})$, protonated $\mathrm{Mn}(\mathrm{HL})$ or $\mathrm{Mn}\left(\mathrm{H}_{2} \mathrm{~L}\right)$ and dinuclear $(\mathrm{Mn}(\mathrm{L}) \mathrm{Cu}))$, as well as the protonation $\left(K_{\mathrm{Mn}(\mathrm{HL})}\right.$ and
$\left.K_{\mathrm{Mn}\left(\mathrm{H}_{2 \mathrm{~L}}\right)}\right)$ and stability constants $\left(K_{\mathrm{Mn}(\mathrm{L}) \mathrm{Cu}}\right)$ of the corresponding intermediates, the following rate equation can be derived $\left(k_{1}=k_{\mathrm{H}} \times K_{\mathrm{Mn}(\mathrm{HL})}\right.$ and $\left.k_{2}=k_{\mathrm{H}}{ }^{\mathrm{H}} \times K_{\mathrm{Mn}(\mathrm{HL})} \times K_{\mathrm{Mn}(\mathrm{HL})}\right)$ :

$k_{o b s}=\frac{k_{0}+k_{1}\left[\mathrm{H}^{+}\right]+k_{2}\left[\mathrm{H}^{+}\right]^{2}+k_{3}\left[\mathrm{Cu}^{2+}\right]}{1+K_{\mathrm{Mn}(\mathrm{HL})}\left[\mathrm{H}^{+}\right]+K_{\mathrm{Mn}(\mathrm{HL})} K_{\mathrm{Mn}\left(\mathrm{H}_{2} \mathrm{~L}\right)}\left[\mathrm{H}^{+}\right]^{2}+K_{\mathrm{Mn}(\mathrm{L}) \mathrm{Cu}\left[\mathrm{Cu}^{2+}\right]}}$

Eqn (2) takes into account all the rational dissociation pathways expected to occur under the experimental conditions used in the current study. Based on the first attempts of data fitting, Eqn (2) was further simplified, as the rate constant characterizing the spontaneous $\left(k_{\mathrm{o}}\right)$ dissociation of the complexes was found to be either negative ([Mn $(3,6-$ $\left.\mathbf{P C}_{2} \mathbf{A}\right)$ ]) or a value with a large standard deviation. This is likely because under these experimental conditions dissociation occurs mainly via an acid assisted pathway, while the contribution of the spontaneous dissociation to the overall reaction is negligible. In case of the $\mathrm{Mn}$ (II) complex of the 3,6-isomer we could not obtain reliable data for the second protonation constant of the complex $\left(K_{\mathrm{Mn}\left(\mathrm{H}_{2} \mathrm{~L}\right)}\right)$, whereas the $K_{\mathrm{Mn}(\mathrm{HL})}$ value determined from kinetic data was found to be 25 times higher $\left(3.6 \times 10^{3} \mathrm{M}^{-1}\right)$ for the $\mathrm{Mn}$ (II) complex of 3,9-isomer than the one determined by $\mathrm{pH}$-potentiometric titration $\left(1.38 \times 10^{2} \mathrm{M}^{-1}\right)$.

The rate constants obtained by fitting the pseudo-firstorder $\left(k_{\text {obs }}\right)$ rate data are presented and compared with those determined for $\mathrm{Mn}$ (II) chelates of PCTA, PC2A-BP, $\mathrm{PC}_{2} \mathrm{~A}-\mathrm{EA}, 6-\mathrm{PC}_{1} \mathrm{~A}$, DOTA, $\mathrm{DO}_{3} \mathrm{~A}, 1,4-\mathrm{DO}_{2} \mathrm{~A}$ and 1,7-DO2A in Table 3. The comparison of the $k_{1}$ rate constants indicates that removal of an acetate pendant arm from the PCTA ligand results in a considerable drop in the inertness of their Mn(II) complexes. A similar drop in terms of inertness is observed when comparing the rate constants characterizing the acid-assisted dissociation of [Mn(DOTA)] and $\left[\mathrm{Mn}\left(\mathrm{DO}_{3} \mathrm{~A}\right)\right]$, and even a more significant decrease on going from $\left[\mathrm{Mn}\left(\mathrm{DO}_{3} \mathrm{~A}\right)\right]$ to the regioisomeric $\left[\mathrm{Mn}\left(1,7^{-}\right.\right.$ $\left.\left.\mathrm{DO}_{2} \mathrm{~A}\right)\right]$ and $\left[\mathrm{Mn}\left(1,4-\mathrm{DO}_{2} \mathrm{~A}\right)\right]$ complexes.

Table 3. Rate and equilibrium constants and half-lives of dissociation ( $\mathrm{pH}=7 \cdot 4)$ for the Mn(II) complexes formed with 3,6- and 3,9-PC2A compared with those determined for PCTA, PC2A-BP, PC2A-EA, 6-PC1A, DOTA, DO3A,

\begin{tabular}{|c|c|c|c|c|c|c|c|}
\hline & $k_{\mathrm{o}}\left(\mathrm{s}^{-1}\right)$ & $k_{1}\left(\mathrm{M}^{-1} \mathrm{~S}^{-1}\right)$ & $k_{2}\left(\mathrm{M}^{-2} \mathrm{~S}^{-1}\right)$ & $k_{3}\left(\mathrm{M}^{-1} \mathrm{~s}^{-1}\right)$ & $K_{\mathrm{Mn}(\mathrm{HL})}$ & $K_{\mathrm{M}(\mathrm{L}) \mathrm{M}}$ & $t_{1} / 2(\mathrm{~h})$ \\
\hline $\mathrm{PCTA}^{a}$ & $(7.0 \pm 0.1) \times 10^{-2 b}$ & $1.09 \times 10^{-1} b / 8.2 \times 10^{-2}$ & $3.5 \times 10^{2}$ & $1.8 \times 10^{-6}$ & $91^{c}$ & $38(\mathrm{Zn})$ & $5.90 \times 10^{4}$ \\
\hline 3,9-PC2A & $--^{d}$ & $221 \pm 5$ & - & $(3.6 \pm 0.7) \times 10^{-2}$ & $(3.6 \pm 0.5) \times 10^{3}$ & $26 \pm 3$ & 21.0 \\
\hline 3,6-PC2A & $-{ }^{d}$ & $70 \pm 1$ & $(1.5 \pm 0.4) \times 10^{5}$ & $(2.6 \pm 0.7) \times 10^{-2}$ & $1.15^{\times 10^{3 c}}$ & $16 \pm 2$ & 63.2 \\
\hline $\mathrm{PC}_{2} \mathrm{~A}-\mathrm{BP} e$ & $-{ }^{d}$ & 16.9 & - & - & 1350 & - & 286 \\
\hline $\mathrm{PC}_{2} \mathrm{~A}-\mathrm{EA}^{f}$ & $--^{d}$ & 0.6 & - & - & 102 & - & $8.00 \times 10^{3}$ \\
\hline $6-\mathrm{PC}_{1} \mathrm{~A}^{g}$ & $-{ }^{d}$ & 2020 & $8 \times 10^{7}$ & - & $8.92 \times 10^{4 c}$ & - & 2.40 \\
\hline DOTA $^{a}$ & $1.8 \times 10^{-7}$ & 0.04 & $1.6 \times 10^{3}$ & $1.5 \times 10^{-5}$ & $4.57 \times 10^{5 c}$ & $68(\mathrm{Zn})$ & 1037 \\
\hline $\mathrm{DO}_{3} \mathrm{~A}^{a}$ & $--^{d}$ & 0.45 & $3.2 \times 10^{2}$ & - & $1.82 \times 10^{4^{c}}$ & - & $1.1 \times 10^{4}$ \\
\hline $1,4-\mathrm{DO}_{2} \mathrm{~A}^{h}$ & $-{ }^{d}$ & 100 & $1.6 \times 10^{6}$ & - & $1.41 \times 10^{4 c}$ & - & 58 \\
\hline $1,7-\mathrm{DO}_{2} \mathrm{~A}^{h}$ & $-^{d}$ & 85 & $3.0 \times 10^{6}$ & - & $2.51 \times 10^{4 c}$ & - & 48 \\
\hline
\end{tabular}
$1,4-\mathrm{DO}_{2} \mathrm{~A}$ and $1,7-\mathrm{DO} 2 \mathrm{~A}\left(\mathrm{~T}=25^{\circ} \mathrm{C}\right.$ and $\left.\mathrm{I}=0.15 \mathrm{M} \mathrm{NaCl}\right)$.

${ }^{a}$ Data from Ref. $16 .{ }^{b}$ Determined by stopped-flow technique in highly acidic solutions, Ref. $16 .{ }^{c}$ The value obtained by $\mathrm{pH}$-potentiometric titration was fixed during the calculations. ${ }^{d}$ Fixed to o for the data fitting. ${ }^{e}$ Data from Ref. 22. ${ }^{f}$ Data from Ref. 21. ${ }^{g}$ Data from Ref. $28 .{ }^{h}$ Data from Ref. $18 .{ }^{I}$ Half-lives of dissociation were calculated at $\mathrm{pH}=7 \cdot 4$ by $\mathrm{using}$ the rate constants and o.o1 mM M(II) ion concentration. 
The dissociation of regioisomeric $\left[\mathrm{Mn}\left(1,7-\mathrm{DO}_{2} \mathrm{~A}\right)\right]$ or $\left[\mathrm{Mn}\left(1,4-\mathrm{DO}_{2} \mathrm{~A}\right)\right]$ complexes occurs with very similar rates (in the studied $\mathrm{pH}$-range), while isomeric $\left[\mathrm{Mn}\left(\mathrm{PC}_{2} \mathrm{~A}\right)\right]$ complexes behave differently as far as their dissociation kinetics is concerned. The most striking difference can be seen when comparing the rates of acid assisted dissociation $\left(k_{1}\right)$, which is slightly more than 3 times higher for the $\left[\mathrm{Mn}\left(3,9-\mathrm{PC}_{2} \mathrm{~A}\right)\right]$ complex than for $\left[\mathrm{Mn}\left(3,6-\mathrm{PC}_{2} \mathrm{~A}\right)\right]$. These differences are also reflected in the half-life values $\left(t_{1 / 2}\right)$ of dissociation calculated at $\mathrm{pH}=7.4$ in the presence of 0.01 $\mathrm{mM}$ exchanging metal ion (Table 3 ). Furthermore, the protonation constant of the $\left[\mathrm{Mn}\left(3,9-\mathrm{PC}_{2} \mathrm{~A}\right)\right]$ complex estimated form the kinetic data appeared to be nearly three times higher than that of $\left[\mathrm{Mn}\left(\mathbf{3}, \mathbf{6}-\mathrm{PC}_{2} \mathrm{~A}\right)\right]$, which indicates that the $\left[\mathrm{Mn}\left(3,9-\mathrm{PC}_{2} \mathrm{~A}\right)\right]$ complex is more prone to the protonation (i.e. formation of protonated intermediate) than $\left[\mathrm{Mn}\left(\mathbf{3}, \mathbf{6}-\mathrm{PC}_{2} \mathrm{~A}\right)\right]$. The electrostatic potential calculated with DFT on the molecular surface defined by o.oor a.u isosurface of the electron density (Figure 2), $3^{8}$ provides a straightforward explanation for this effect. The two complexes present rather different charge distributions (Figure 2). As expected, the most negative electrostatic potential resides on the negatively charged carboxylate groups. The electrostatic potential on the molecular surface of $\left[\mathrm{Mn}\left(\mathbf{3}, \mathbf{9}-\mathrm{PC}_{2} \mathrm{~A}\right)\left(\mathrm{H}_{2} \mathrm{O}\right)\right]$ reaches more negative values (ca. -0.16 a.u.) than for $\left[\mathrm{Mn}\left(3,6-\mathrm{PC}_{2} \mathrm{~A}\right)\left(\mathrm{H}_{2} \mathrm{O}\right)\right]$ (ca. -0.10 a.u., Figure 2). As a result, the complex with $3,9-\mathrm{PC}_{2} \mathrm{~A}$ is more readily protonated, favoring the proton-assisted dissociation mechanism.

Dissociation of the Mn(II) complexes in human blood serum. Proteins present in the blood serum (albumin is the most abundant serum protein) are known to bind the essential metal ions relatively strongly. MRI CAs are administered in the order of grams per injection, and thus plasma proteins could potentially initiate transmetallation processes. This issue is particularly critical for $\mathrm{Mn}$ (II) complexes whose thermodynamic stability is lower than the stability of the chelates formed with essential metal ions such as $\mathrm{Zn}(\mathrm{II}), \mathrm{Cu}(\mathrm{II})$. The binding of $\mathrm{Mn}$ (II) to HSA results in an increase of relaxivity from $7.92 \mathrm{mM}^{-1} \mathrm{~s}^{-1}$ measured for the $\mathrm{Mn}$ (II) ion in water solution to $97.2 \mathrm{mM}^{-1} \mathrm{~s}^{-1}$ at $0.47 \mathrm{~T}$, $25^{\circ} \mathrm{C}$ for the Mn(HSA) adduct. 39 Therefore, mixing a kinetically labile and thermodynamically less stable chelate with a Seronorm ${ }^{\circledast}$ solution is expected to provoke the dissociation of the chelate, resulting in a notable increase in the relaxation rate of the sample, as observed for Mn(II) chelates formed with open-chain ligands. ${ }^{9}$ However, the relaxation rate of the samples containing $\left[\mathrm{Mn}\left(3,6-\mathrm{PC}_{2} \mathrm{~A}\right)\right]$ and $\left[\mathrm{Mn}\left(3,9-\mathrm{PC}_{2} \mathrm{~A}\right)\right]$ chelates remain constant for at least 120 and $190 \mathrm{~h}$ respectively, indicating the negligible dissociation of the complex in serum solution prepared from Seronorm (Figure S36, Supporting Information). One should note that the relaxivity of the complexes measured in Seronorm solutions is somewhat higher also than that measured in pure aqueous solution indicating a weak interaction of the uncharged complexes with serum components.
${ }^{17} \mathrm{O}$ NMR measurements. The efficiency of $\mathrm{Mn}$ (II) based MRI contrast agents depends on different microscopic parameters, an important one being the exchange rate of the coordinated water molecule(s), $k_{\text {ex }} .^{\circ}$ Water exchange can be conveniently determined from the temperature dependence of ${ }^{17} \mathrm{O}$ transverse relaxation rates, which are largely dominated by the scalar mechanism. ${ }^{41}$ The observed reduced transverse relaxation rates $1 / T_{2 \mathrm{r}}$ depend on the water exchange rate at $298 \mathrm{~K}, k_{\mathrm{ex}}{ }^{298}$, and its activation enthalpy $\Delta H^{\ddagger}$, the relaxation time of the electron spin $T_{2 \mathrm{e}^{298}}$, and the ${ }^{17} \mathrm{O}$ hyperfine coupling constant $A / \hbar$. Furthermore, ${ }^{17} \mathrm{O}$ NMR chemical shifts provide direct access to $A / \hbar .{ }^{42}$

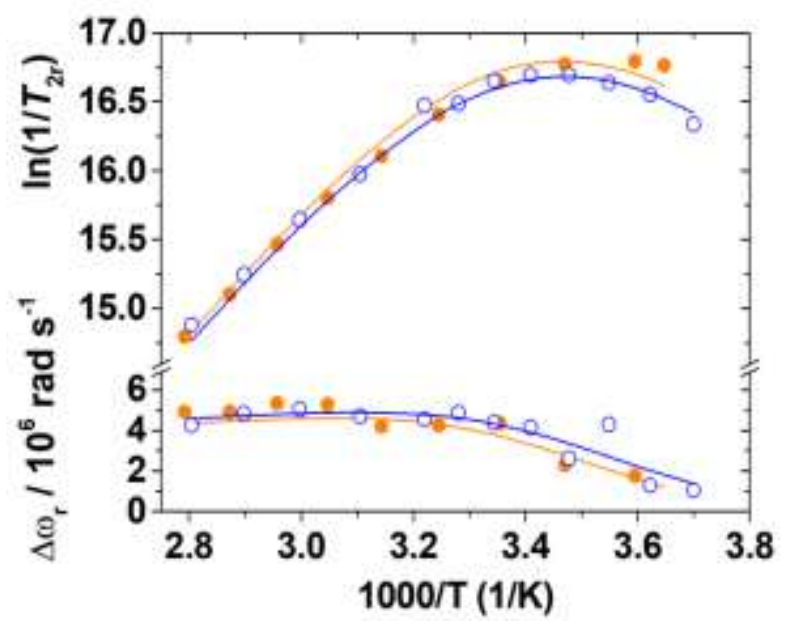

Figure 4. Reduced transverse ${ }^{17} \mathrm{O}$ relaxation rates and chemical shifts for the $\mathrm{Mn}(\mathrm{II})$ complexes of 3,6-PC2A (open blue circles) and 3,9-PC2A (closed orange circles) measured at 9.4 $\mathrm{T}$. The solid lines correspond to the fits of the data as described in the text.

The reduced transverse relaxation rates and chemical shifts recorded for $\left[\mathrm{Mn}\left(\mathbf{3}, \mathbf{6}-\mathrm{PC}_{2} \mathrm{~A}\right)\left(\mathrm{H}_{2} \mathrm{O}\right)\right]$ and $\left[\mathrm{Mn}\left(3,9-\mathrm{PC}_{2} \mathrm{~A}\right)\left(\mathrm{H}_{2} \mathrm{O}\right)\right]$ are very similar, both indicating a changeover from a fast-exchange regime at high temperatures to an intermediate exchange regime at low temperatures. The two complexes present a maximum in the plot of $1 / T_{2 \mathrm{r}}$ at about the same temperature, which anticipates very similar water exchange rates. The relaxivity at this maximum can be used to estimate the hydration number of the complexes using the method proposed by Gale. ${ }^{43} \mathrm{We}$ obtained a value of $q$ of 0.7 , which confirms the formation of monohydrated complexes in solution.

The fits of the reduced relaxation rates and chemical shifts afforded the parameters shown in Table 4. According to the parameters obtained in this analysis, the contribution of the electron spin relaxation term $1 / T_{1 \mathrm{e}}$ to the transverse relaxation rate varies between $79-10 \%$ and $49-8 \%$ for $\left[\mathrm{Mn}\left(3,6-\mathrm{PC}_{2} \mathrm{~A}\right)\left(\mathrm{H}_{2} \mathrm{O}\right)\right]$ and $\left[\mathrm{Mn}\left(3,9-\mathrm{PC}_{2} \mathrm{~A}\right)\left(\mathrm{H}_{2} \mathrm{O}\right)\right]$, respectively, in the temperature range $0-75{ }^{\circ} \mathrm{C}$. The relatively small contribution of the electron spin relaxation in the fast exchange limit ensures that the value calculated for the water exchange rate is correct. 
Table 4. Best-fit parameters obtained from the analysis of ${ }^{17} \mathrm{O}$ NMR chemical shifts and reduced relaxation rates of $\left[\mathrm{Mn}(3,6-\mathrm{PC} 2 \mathrm{~A})\left(\mathrm{H}_{2} \mathrm{O}\right)\right],\left[\mathrm{Mn}\left(3,9-\mathrm{PC}_{2} \mathrm{~A}\right)\left(\mathrm{H}_{2} \mathrm{O}\right)\right]$ and $\left[\mathrm{Mn}\left(1,4-\mathrm{DO}_{2} \mathrm{~A}\right)\left(\mathrm{H}_{2} \mathrm{O}\right)\right]$ recorded at $9.4 \mathrm{~T}^{a}$

$\begin{array}{llll} & 3,6-\mathrm{PC}_{2} \mathrm{~A} & 3,9-\mathrm{PC}_{2} \mathrm{~A} & 1,4-\mathrm{DO}_{2} \mathrm{~A} \\ k_{\mathrm{ex}}{ }^{298} / 10^{6} \mathrm{~s}^{-1} & 140 \pm 25 & 126 \pm 12 & 1134 \\ \Delta H^{\ddagger} / \mathrm{kJ} \mathrm{mol}^{-1} & 38.2 \pm 3.9 & 37.5 \pm 2.4 & 29.4 \\ A_{\mathrm{O}} / \hbar / 10^{6} \mathrm{rad} \mathrm{s}^{-1} & -44.6 \pm 1.8 & -42.4 \pm 1.9 & -43.0 \\ 1 / T_{2 \mathrm{e}^{298}} / 10^{8} \mathrm{~s}^{-1} & 1.8 \pm 0.6 & 1.1 \pm 0.3 & 1.0\end{array}$

${ }^{a}$ Data from Ref.4.

In the case of $\mathrm{Mn}(\mathrm{II})$, water exchange is typically accelerated upon complexation. The water exchange rates determined for the two complexes are very similar, and indeed, they are about five times higher than that on the aqua ion $\left(k_{\mathrm{ex}}{ }^{298}=28.2 \times 10^{6} \mathrm{~s}^{-1}\right)$. However, the water exchange rates determined for $\left[\mathrm{Mn}\left(\mathbf{3}, 6-\mathrm{PC}_{2} \mathrm{~A}\right)\left(\mathrm{H}_{2} \mathrm{O}\right)\right]$ and $\left[\mathrm{Mn}\left(\mathbf{3}^{3}, \mathbf{9}^{-}\right.\right.$ $\left.\mathbf{P C}_{2} \mathbf{A}\right)\left(\mathrm{H}_{2} \mathrm{O}\right)$ ] are still $\sim 3.5$ times lower than that reported for $\left[\mathrm{Mn}(\mathrm{EDTA})\left(\mathrm{H}_{2} \mathrm{O}\right)\right]^{2-}\left(k_{\mathrm{ex}}{ }^{298}=471 \times 10^{6} \mathrm{~s}^{-1}\right) .4$ The structurally related $\left[\mathrm{Mn}\left(1,4-\mathrm{DO}_{2} \mathrm{~A}\right)\left(\mathrm{H}_{2} \mathrm{O}\right)\right]$ complex presents a water exchange rate that is one order of magnitude higher (Table 4). This fast water exchange was ascribed to an important degree of steric compression around the water binding site, which favors water exchange following a dissociative mechanism. This steric compression is even higher in $\left[\mathrm{Mn}\left(1,7-\mathrm{DO}_{2} \mathrm{~A}\right)\right]$, which does not contain a coordinated water molecule. Thus, the incorporation of a pyridyl group into the 12-membered macrocyclic unit favors the coordination of a water molecule to the metal center (Table $\mathrm{S}_{3}$, Supporting Information).

The water exchange rates determined for $[\mathrm{Mn}(3,6-$ PC2 $\left.\mathbf{A})\left(\mathrm{H}_{2} \mathrm{O}\right)\right]$ and $\left[\mathrm{Mn}\left(3,9-\mathbf{P C}_{2} \mathbf{A}\right)\left(\mathrm{H}_{2} \mathrm{O}\right)\right]$ can be regarded as rather low when compared to those reported for typical $\mathrm{Mn}(\mathrm{II})$ chelates. The similar water exchange rates measured for the two complexes are in line with the structures obtained with DFT calculations, which predict very similar Mn- $\mathrm{O}_{\text {water }}$ distances (2.270 and $2.279 \AA$ for $[\mathrm{Mn}(3,6-$ $\left.\left.\mathbf{P C}_{2} \mathrm{~A}\right)\left(\mathrm{H}_{2} \mathrm{O}\right)\right]$ and $\left[\mathrm{Mn}\left(3,9-\mathrm{PC}_{2} \mathrm{~A}\right)\left(\mathrm{H}_{2} \mathrm{O}\right)\right]$, respectively, Table $\mathrm{S}_{3}$, Supporting Information). DFT calculations provided ${ }^{17} \mathrm{O} \mathrm{A}_{\mathrm{O}} / \hbar$ values of $-39.8 \times 10^{6}$ and $-40.7 \times 10^{6} \mathrm{rad} \cdot \mathrm{s}^{-1}$, which are in excellent agreement with those obtained from the fits of the ${ }^{17} \mathrm{O}$ NMR data. These values fall in the upper range of the values normally observed for $\mathrm{Mn}(\mathrm{II})$ complexes $\left(-31 \times 10^{6}\right.$ to $\left.-46 \times 10^{6} \mathrm{rad} \cdot \mathrm{s}^{-1}\right) .4,43$ The excellent agreement between the experimental and calculated data confirms that the assumption that $q=1$ is correct. Thus, the slightly higher relaxivity observed for the 3,9-PC2A complex is likely related to a slightly shorter $\mathrm{Mn} \cdots \mathrm{H}$ distance, as the dipolar relaxation rate of the coordinated water molecule is inversely proportional to the sixth power of this distance.

CV measurements. The potential oxidation of a $\mathrm{Mn}$ (II) based contrast agent may have a negative impact in the re- laxivity of the agent, as $\mathrm{Mn}$ (III) complexes with polyaminopolycarboxylate ligands generally present lower relaxivities with respect to the $\mathrm{Mn}$ (II) counterparts. ${ }^{44}$ Thus, we carried out cyclic voltammetry experiments using aqueous solutions of the complexes in $0.15 \mathrm{M} \mathrm{NaCl}$ (Figure 5). The cyclic voltammogram of the complex with 3,6-PC2A recorded at a scan rate of $50 \mathrm{mV} \mathrm{s}{ }^{-1}$ displays an oxidation peak at $E_{\mathrm{ox}}=+862 \mathrm{mV}$ and a reduction peak at $E_{\mathrm{red}}=+579 \mathrm{mV}$ $\left(\Delta E_{1 / 2}=720 \mathrm{mV} v s . \mathrm{Ag} / \mathrm{AgCl}\right)$. The cyclic voltammogram of the 3,9-PC2A complex is characteristic of an irreversible system, showing an oxidation peak at $E_{\mathrm{ox}}=+838 \mathrm{mV}$ and a very faint reduction signal at $E_{\text {red }} \sim+340 \mathrm{mV}$. The irreversibility of the cyclovoltammetric curves is likely related to the seven-coordinate environment, which likely requires an important reorganization to the octahedral coordination preferred by $\mathrm{Mn}(\mathrm{III}) .45$ The electrochemical redox behavior of the complexes appears to be controlled by diffusion, as the cathodic and anodic current intensities vary linearly with the square root of the scan rate in the range $10-300 \mathrm{mV} \mathrm{s}^{-1}$ for 3,6-PC2 $\mathrm{A}$ and 3,9-PC2 $\mathrm{A}$ respectively (Figures $\mathrm{S}_{31-32}$, Supporting Information).S37-S38

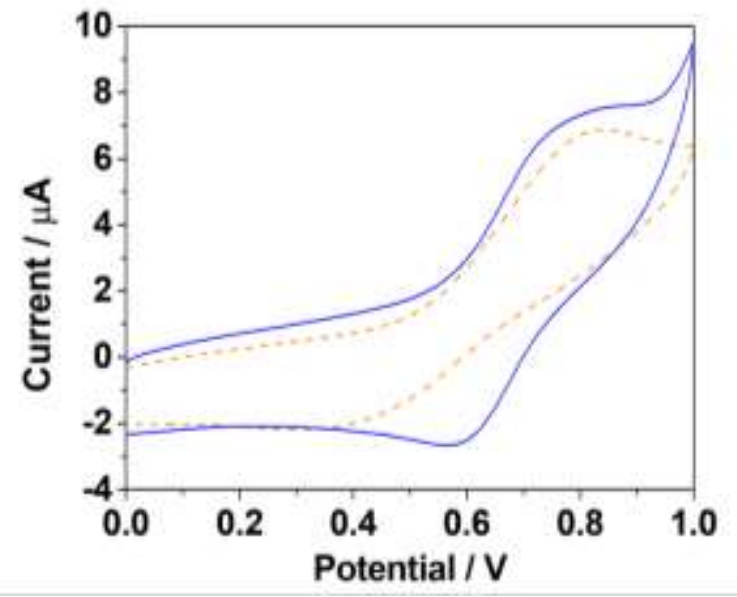

Figure 5: Cyclic voltammograms recorded for the $\mathrm{Mn}^{2+}$

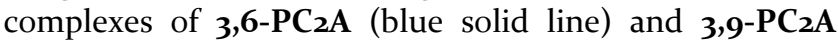
(dashed orange line). Conditions: $2 \mathrm{mM}, \mathrm{pH}=7.1$, $0.15 \mathrm{M}$ $\mathrm{NaCl}$, scan rate $50 \mathrm{mV} / \mathrm{s}$, potentials reported $v s$. $\mathrm{Ag} / \mathrm{AgCl}$ ).

The $\mathrm{Mn}$ (II) complexes with 3,6-PC2 $\mathrm{A}$ and 3,9-PC2A present very similar $E_{\text {ox }}$ values, and therefore similar abilities to stabilize $\mathrm{Mn}$ (III). The $E_{\mathrm{ox}}$ values determined for the complexes of 3,6 and 3,9-PC2A complexes are shifted to higher potentials with respect to the values reported for $[\operatorname{Mn}(\mathrm{EDTA})]_{2}\left(E_{\mathrm{ox}}=769 \mathrm{mV}\right)$ and $[\mathrm{Mn}(\mathrm{PhDTA})]_{2}\left(E_{\mathrm{ox}}=813\right.$ $\mathrm{mV}$ ) under the same conditions, ${ }^{11}$ which indicates that the $\mathrm{PC}_{2} \mathrm{~A}$ complexes reported here have a lower tendency to stabilize Mn(III).

SOD activity of $\mathrm{Mn}\left(3,6-\mathrm{PC}_{2} \mathrm{~A}\right)$ and $\mathrm{Mn}\left(3,9-\mathrm{PC}_{2} \mathrm{~A}\right)$ complexes. The SOD activity of the Mn(II) complexes was tested using the xanthine/xanthine oxidase/NBT assay at $\mathrm{pH} 7.8 .4^{4}$ The inhibition curves as a function of complex 
concentration are shown in Figure S39 (Supporting Information). It is important to note that $\mathrm{Mn}$ (II) salts exhibit significant SOD activities, ${ }^{47}$ therefore the species distributions were recalculated for each $\mathrm{Mn}$ (II) concentration used in the SOD activity studies. These distribution curves clearly confirm that the $\mathrm{Mn}(\mathrm{II})$ is bound to the ligands under the conditions of SOD activity studies and the complexes do not dissociate even at the $\mu \mathrm{M}$ concentration level. Thus, the free Mn(II) does not affect the decomposition of superoxide anion radical.

The $\mathrm{IC}_{50}$ value was estimated to be $26.1 \mu \mathrm{M}$ and $136 \mu \mathrm{M}$ for $\left[\mathrm{Mn}\left(3,6-\mathrm{PC}_{2} \mathrm{~A}\right)\right]$ and $\left[\mathrm{Mn}\left(\mathbf{3}, \mathbf{9}-\mathrm{PC}_{2} \mathrm{~A}\right)\right]$, respectively. However, the Mn(II) complex of PCTA did not exhibit any SOD activity up to a $240 \mu \mathrm{M}$ concentration level. From the $\mathrm{IC}_{50}$ values, it is also possible to calculate the kinetic rate constant, $k_{\mathrm{McCF}}$, for the SOD activity using Eqn (3):

$$
k_{\mathrm{McCF}}=k_{\mathrm{NBT}} \times \frac{[\mathrm{NBT}]}{\mathrm{IC}_{50}}
$$

where $k_{\mathrm{NBT}}$ is $5.94 \times 10^{4} \mathrm{M}^{-1} \mathrm{~S}^{-1}$ for NBT (at $\mathrm{pH} 7.8$; In our assay, the concentration of NBT was $45 \mu \mathrm{M}$ ). Since $k_{\mathrm{McCF}}$ does not depend on the concentration of the detector molecule and its nature, it is frequently used to compare directly the activities of different complexes. The calculated $k_{\mathrm{McCF}}$ values are summarized in Table $\mathrm{S}_{4}$ (Supporting Information). The results demonstrate that $\mathrm{Mn}$ (II) complexes of 3,6-PC2A and 3,9-PC2A, are capable to assist the decomposition of superoxide anion radical. The kinetic rate constant of the complex of 3,9-PC2A is smaller by one order of magnitude than that of $3,6-\mathrm{PC}_{2} \mathrm{~A}$, while the PCTA analogue does not have any activity. Thus, the presence of inner sphere water molecule contributes to the efficient degradation of the superoxide anion radical. The coordinated water molecule in the $\mathrm{PC}_{2} \mathrm{~A}$ complexes likely provides an accessible coordination sites for interaction with $\mathrm{O}_{2}{ }^{-{ }^{-}}$or peroxides. The $[\mathrm{Mn}(\mathrm{PCTA})]^{-}$complex does not possess any metal bound water molecule, preventing the redox processes between the superoxide anion and $\mathrm{Mn}(\mathrm{II})$. The less negative electrostatic potential on the molecular surface of the $\left[\mathrm{Mn}\left(3,6-\mathrm{PC}_{2} \mathbf{A}\right)\left(\mathrm{H}_{2} \mathrm{O}\right)\right]$ complexes likely facilitates a stronger coordination of the superoxide radical, resulting in an enhanced catalytic activity compared with the 3,9-PC2A analogue (Figure 2). Nevertheless, it is important to note that the catalytic activities of these complexes are considerably smaller than those reported for other $\mathrm{Mn}$ (II) complexes bearing a $\mathrm{N}$-tripodal scaffold or pentadentate ligands derived from ethylenediamine. ${ }^{48,49}$

\section{CONCLUSIONS}

In conclusion, in the current study we have shown that the $\mathrm{Mn}(\mathrm{II})$ complexes formed with 3,6- and 3,9-PC2A regioisomeric ligands possess different physico-chemical properties. The relevant physico-chemical data (thermodynamic and redox stability, dissociation and solvent exchange kinetics, and relaxivity values (at $25^{\circ} \mathrm{C}$ )) are collected and compared in Table 5 . The most pronounced differences among the two regioisomeric complexes concern the stability, dissociation kinetics and relaxivity values.
The $\left[\mathrm{Mn}\left(\mathbf{3}, \mathbf{9}-\mathbf{P C}_{2} \mathrm{~A}\right)\right]$ complex possesses better thermodynamic stability (higher $\log K_{[\mathrm{Mn}(\mathrm{L})]}$ and $\mathrm{pMn}$ ) and relaxometric properties $\left(r_{1 \mathrm{p}} / r_{2 \mathrm{p}}\right.$ at 25 and $37^{\circ} \mathrm{C}$ at both field strengths assessed), while the $\left[\mathrm{Mn}\left(3,6-\mathrm{PC}_{2} \mathrm{~A}\right)\right]$ chelate has superior kinetic inertness, based on metal exchange reactions occurring with essential metal ions. In overall, both chelates can serve as suitable "building blocks" when tailoring inert $\mathrm{Mn}$ (II) complexes for safe MRI applications, as well as for designing "smart"/responsive imaging probes.

Table 5 Comparison of the most relevant physicochemical data of the Mn(II) complexes formed with 3,6-PC $2 \mathrm{~A}$ and $3,9-\mathrm{PC} 2 \mathrm{~A}$ ligands $\left(25^{\circ} \mathrm{C}\right.$ and $\left.0.15 \mathrm{M} \mathrm{NaCl}\right)$.

$\begin{array}{lll} & {\left[\mathrm{Mn}\left(3,6-\mathrm{PC}_{2} \mathrm{~A}\right)\right]} & {[\mathrm{Mn}(3,9-\mathrm{PC} 2 \mathrm{~A})]} \\ \log K_{[\mathrm{Mn}(\mathrm{L})]} & 15.53 & 17.09 \\ \mathrm{pMn}^{a} & 8.03 & 8.64 \\ t_{1 / 2}(\mathrm{~h})^{b} & 63.2 & 21.0 \\ k_{\mathrm{ex}}{ }^{298}\left(\times 10^{6} \mathrm{~s}^{-1}\right) & 140 & 126 \\ E_{\mathrm{ox}} / \mathrm{mV}^{c} & 862 & 838 \\ r_{1 \mathrm{p} /} / r_{2 \mathrm{p}} 298\left(\mathrm{mM}^{-1} \mathrm{~s}^{-1}\right)^{d} & 2.72 / 3.49 & 2.91 / 3.96\end{array}$

${ }^{a} \mathrm{pMn}$ values were calculated at $\mathrm{pH}=7.4$ by using $0.01 \mathrm{mM}$ $\mathrm{Mn}(\mathrm{II})$ and ligand concentration as suggested by É. Tóth and co-workers, Ref. ; ${ }^{b}$ the half-lives (h) of dissociation were calculated at $\mathrm{pH}=7.4$ by using the rate constants and $0.01 \mathrm{mM} \mathrm{Cu}(\mathrm{II})$ ion concentration. ${ }^{\mathrm{c}}$ Scan rate $50 \mathrm{mV} \mathrm{s}-1$, $\mathrm{pH}$ 7.1, $0.15 \mathrm{M} \mathrm{NaCl} .{ }^{d}$ At 0.49 T field strength.

\section{EXPERIMENTAL SECTION}

Materials and methods. Reagents were purchased from ACROS Organics and from Aldrich Chemical Co and used without further purification. Dialysis membranes (cut-off 100-500 Da) were purchased from Repligen. All solvents were dried and distilled prior to use according to standard methods. Compound $\mathbf{1}^{24}$ was synthesized as previously described. The 3,9-PC2A ligand was prepared according to literature procedures, starting form commercially available dipicolinic acid and diethylene-triamine. 23,50 The corresponding $\mathrm{Mn}(\mathrm{II})$ complex was prepared by mixing stock solutions of the ligand and metal ion and $\mathrm{pH}$ adjustment to the desired value. Syntheses of compounds $\mathbf{2 ,}, \mathbf{3}, \mathbf{5}, \mathbf{6}$, the $\mathrm{Mn}$ (II) complex of 3,6-PC2A and corresponding analyses including HPLC, NMR and HRMS are given in the supporting information (Scheme S1, Figure S1 to S29). Analytical HPLC was performed on a Prominence Shimadzu HPLC/LCMS-2020 equipped with a UV SPD-20 A detector. HPLC separation on Prep C18 AQ $5 \mu$ M $250 \times 4.6 \mathrm{~mm}$ column was performed with $\mathrm{H}_{2} \mathrm{O}+0.1 \%$ TFA and $\mathrm{MeOH}$ as eluents at a flow rate of $1 \mathrm{~mL} / \mathrm{min}$ and UV detection at 254 and $350 \mathrm{~nm}$. NMR spectra were recorded at the "Services communs" of the University of Brest. ${ }^{1} \mathrm{H}$ and ${ }^{3} \mathrm{C}$ NMR spectra were recorded using Bruker Avance 500 (500 MHz), Bruker Avance 400 (400 MHz), or BrukerAMX-3 300 (300 
$\mathrm{MHz}$ ) spectrometers. HRMS analyses were performed on a HRMS Q-Tof MaXis instrument equipped with ESI, APCI, APPI and nano-ESI sources (at the Institute of Organic and Analytic Chemistry (ICOA), University of Orléans, Orléans, France). Numbering of the hydrogens and carbons of the molecules are given in the supporting information.

Synthesis. Compound 4. A solution of compound 1 (3.10 g, $11.9 \mathrm{mmol}$ ) and $\mathrm{NaHCO}_{3}(2.00 \mathrm{~g}, 23.8 \mathrm{mmol}, 2$ equiv) in $\mathrm{CH}_{3} \mathrm{CN}(238 \mathrm{~mL})$ was stirred at room temperature for 40 min. Alloc-Cl (1.33 mL, $12.5 \mathrm{mmol}, 1.05$ equiv) was added dropwise to this solution. The reaction mixture was stirred at room temperature for $14 \mathrm{~h}$. Salts were filtered and the filtrate was evaporated to dryness. The residue was taken up in dichloromethane and the residual salts were filtered. The filtrate was evaporated to dryness to give 4 ( $4.08 \mathrm{~g}$, 11.8 mmol, $99 \%$, mixture of two rotamers) as a white foam. ${ }^{1} \mathrm{H}$ NMR $\left(500 \mathrm{MHz}, \mathrm{CDCl}_{3}\right) \delta 7.52\left(\mathrm{t}, J=7.7 \mathrm{~Hz}, 1 \mathrm{H}, \mathrm{H}_{13}\right.$ of the first rotamer), $7.51(\mathrm{t}, J=7.7 \mathrm{~Hz}, 1 \mathrm{H}, \mathrm{H} 13$ of the second rotamer), $7.10(\mathrm{~d}, J=7.5 \mathrm{~Hz}, 1 \mathrm{H}, \mathrm{H} 12$ of the first rotamer), 7.01 $(\mathrm{d}, J=8 . \mathrm{o} \mathrm{Hz}, \mathrm{H}, \mathrm{H} 14$ of the first rotamer), $7.0 \mathrm{o}(\mathrm{d}, J=8 . \mathrm{o}$ $\mathrm{Hz}, 1 \mathrm{H}, \mathrm{H}_{14}$ of the second rotamer), $6.96(\mathrm{~d}, J=7.5 \mathrm{~Hz}, 1 \mathrm{H}$, $\mathrm{H} 12$ of the second rotamer), 5.81 (ddt, $J=16.3,10.5,5.8 \mathrm{~Hz}$, $1 \mathrm{H}, \mathrm{H} 2 \mathrm{O}$ of the first rotamer), 5.62 (ddd, $J=16.1,10.8,5.5 \mathrm{~Hz}$, $1 \mathrm{H}, \mathrm{H} 2 \mathrm{O}$ of the second rotamer), $5.53(\mathrm{~d}, J=16.9 \mathrm{~Hz}, 2 \mathrm{H}$, Hza of both rotamers), 5.19 (dd, $J=17.2,1.3 \mathrm{~Hz}, 1 \mathrm{H}, \mathrm{H} 21 \mathrm{a}$ of the first rotamer), 5.13 (dd, $J=10.4$, $1.0 \mathrm{~Hz}, 1 \mathrm{H}, \mathrm{H} 21 \mathrm{~b}$ of the first rotamer), 4.99 (dd, $J=10.5,1.2 \mathrm{~Hz}, 1 \mathrm{H}, \mathrm{H} 21 \mathrm{~b}$ of the second rotamer), $4.92(\mathrm{dd}, J=17.2,1.5 \mathrm{~Hz}, 1 \mathrm{H}, \mathrm{H} 21 \mathrm{a}$ of the second rotamer), $4.61\left(\mathrm{~d}, J=14.3 \mathrm{~Hz}, 1 \mathrm{H}, \mathrm{CH}_{2}\right.$ pyclen), 4.55 (d, $J=14.8 \mathrm{~Hz}, 1 \mathrm{H}, \mathrm{CH}_{2}$ pyclen $), 4.47(\mathrm{~d}, J=5.8 \mathrm{~Hz}, 2 \mathrm{H}$, H19 of one rotamer), $4.42-4.31(\mathrm{~m}, 2 \mathrm{H}), 4.21(\mathrm{~d}, J=13.8 \mathrm{~Hz}, 1 \mathrm{H})$, $4.14(\mathrm{~m}, 1 \mathrm{H}), 4.06\left(\mathrm{~d}, J=16.9 \mathrm{~Hz}, 1 \mathrm{H}, \mathrm{H}_{4}\right.$ of the first rotamer), $4.04\left(\mathrm{~d}, J=16.9 \mathrm{~Hz}, 1 \mathrm{H}, \mathrm{H}_{4}\right.$ of the second rotamer), $3.88-3.78(\mathrm{~m}, 4 \mathrm{H}), 3.75-3.51(\mathrm{~m}, 7 \mathrm{H}), 3.31(\mathrm{ddd}, J=14.7$, $11.2,3.9 \mathrm{~Hz},{ }_{1} \mathrm{H}, \mathrm{CH}_{2}$ pyclen), $3.13-3.00(\mathrm{~m}, 4 \mathrm{H}) .{ }^{13} \mathrm{C}$ NMR $\left(125 \mathrm{MHz}, \mathrm{CDCl}_{3}\right) \delta 162.9,162.8\left(\mathrm{C}_{16}\right), 159.3,159.2\left(\mathrm{C}_{17}\right)$, 156.5, 156.4, 156.18 (C11, C18), 153.3, 153.0 (C1), 137.3, 137.1 (C13), 132.2 (C20), 122.1, 121.61 (C12), 119.8, 119.7 (C14), 118.2, 117.2 (C21), 66.1, $65.7\left(\mathrm{C}_{18}\right)$, 58.7, 57.5, 57.0, 56.8, 51.1, 49.9, 48.9, 48.8, 47.8, 46.8, 45.5, 45.4 ( $\mathrm{CH}_{2}$ pyclen). ESI-HR-MS (positive) $\mathrm{m} / \mathrm{z}$ calcd. for $\left[\mathrm{C}_{17} \mathrm{H}_{21} \mathrm{~N}_{4} \mathrm{O}_{4}\right]^{+}: 345.1557$, found: 345.1557, $[\mathrm{M}+\mathrm{H}]^{+}$; calcd. for $\left[\mathrm{C}_{17} \mathrm{H}_{20} \mathrm{~N}_{4} \mathrm{NaO}_{4}\right]^{+}: 367.1377$, found: $367.1374,[\mathrm{M}+\mathrm{Na}]^{+}$.

Compound 7. A solution of compound 4 (4.04 g, 11.7 $\mathrm{mmol})$ in $2 \mathrm{M} \mathrm{HCl}(50 \mathrm{~mL})$ was stirred at $100^{\circ} \mathrm{C}$ for $5.5 \mathrm{~h}$ and then cooled down to room temperature before addition of $\mathrm{H}_{2} \mathrm{O}(7 \mathrm{o} \mathrm{mL})$ and amberlist A21 resin (75.o g) to remove the excess of the acid. The mixture was slowly stirred for $1 \mathrm{~h}$ before filtration of the resin which was washed with water and $\mathrm{MeOH}$. The filtrate was evaporated to dryness to give a yellow oil. Exchange of the counter-ion was performed on a column of amberlite IRA $458\left(\mathrm{OH}^{-}\right.$form, $\left.56 \mathrm{~mL}\right)$ with $\mathrm{MeOH}$ as an eluent. Purification of the oil was performed by several precipitations (first precipitation with $\mathrm{MeOH} / \mathrm{Et}_{2} \mathrm{O}$, 2nd precipitation with hot $\mathrm{CH}_{3} \mathrm{CN}$, third precipitation with $\mathrm{MeOH} / \mathrm{AcOEt}$ ) and by column chromatography on neutral alumina (eluent: $\mathrm{CH}_{2} \mathrm{Cl}_{2} / \mathrm{MeOH} 100 / \mathrm{o}$ to
$100 / 2$ ) to give compound 7 ( $3.37 \mathrm{~g}, 11.5 \mathrm{mmol}, 98 \%, 1 / 1 \mathrm{mix}-$ ture of two rotamers) as a white solid. ${ }^{1} \mathrm{H}$ NMR $(500 \mathrm{MHz}$, $\left.\mathrm{D}_{2} \mathrm{O}\right) \delta_{7.67}(\mathrm{t}, J=7.3 \mathrm{~Hz}, 2 \mathrm{H}, \mathrm{H} 13$ of the two rotamers), 7.19 (d, $J=6.5 \mathrm{~Hz}, \mathrm{H12}$ of the first rotamer), $7.18(\mathrm{~d}, J=6.5 \mathrm{~Hz}$, $\mathrm{H}_{12}$ of the second rotamer), $7.12\left(\mathrm{~d}, J=7.6 \mathrm{~Hz}, 2 \mathrm{H}, \mathrm{H}_{14}\right.$ of the two rotamers), 6.00 (ddt, $J=16.3,10.8,5.6 \mathrm{~Hz}, 1 \mathrm{H}, \mathrm{Hr}$ of the first rotamer), 5.71 (ddt, $J=16.0,10.3,4.9 \mathrm{~Hz}, 1 \mathrm{H}, \mathrm{H}_{17}$ of the second rotamer), $5.36(\mathrm{~d}, J=17.2 \mathrm{~Hz}, 2 \mathrm{H}, \mathrm{H} 18 \mathrm{a}$ of the first rotamer), $5.28(\mathrm{~d}, J=10.6 \mathrm{~Hz}, 2 \mathrm{H}, \mathrm{H} 18 \mathrm{~b}$ of the first rotamer), $5.06(\mathrm{~d}, J=10.0 \mathrm{~Hz}, 1 \mathrm{H}, \mathrm{H1} 8 \mathrm{~b}$ of the second rotamer), $5.04(\mathrm{~d}, J=16.7 \mathrm{~Hz}, 1 \mathrm{H}, \mathrm{H} 18 \mathrm{a}$ of the second rotamer), $4.65-4.55(\mathrm{~m}, 6 \mathrm{H}, \mathrm{H} 16$ of the first rotamer $), 4.45(\mathrm{~d}, J=4.6$ $\mathrm{Hz}, 2 \mathrm{H}, \mathrm{H} 16$ of the second rotamer), $3.91(\mathrm{~d}, J=7.9 \mathrm{~Hz}, 4 \mathrm{H})$, $3.76-3.66(\mathrm{~m}, 4 \mathrm{H}), 2.82(\mathrm{~s}, 4 \mathrm{H}), 2.61-2.55(\mathrm{~m}, 2 \mathrm{H}), 2.45$ $(\mathrm{d}, J=3.2 \mathrm{~Hz}, 4 \mathrm{H}), 2.37(\mathrm{~s}, 2 \mathrm{H}) .{ }^{13} \mathrm{C}$ NMR $\left(126 \mathrm{MHz}, \mathrm{D}_{2} \mathrm{O}\right) \delta$ $161.9(\mathrm{Cq}), 161.8(\mathrm{Cq}), 160.9$ ( $\mathrm{C}_{15}$ of the first rotamer), 160.7 ( $\mathrm{C}_{15}$ of the second rotamer), $159.1(\mathrm{Cq}), 158.7(\mathrm{Cq}), 140.7$ ( $\mathrm{C}_{13}$ ), 135.4 ( $\mathrm{C}_{17}$ of the first rotamer), 135.2 ( $\mathrm{C}_{17}$ of the second rotamer), 123.4, 122.7, 122.7 ( $\mathrm{C}_{12}$ and $\mathrm{C}_{14}$ of both rotamers), 121.1 ( $\mathrm{C}_{18}$ of the first rotamer), 119.5 ( $\mathrm{C}_{1} 8$ of the second rotamer), 69.4 ( $\mathrm{C}_{16}$ of the first rotamer), 69.1 ( $\mathrm{C}_{18}$ of the second rotamer), 55.2 $\left(\mathrm{CH}_{2}\right), 54.7\left(\mathrm{CH}_{2}\right), 53.9\left(\mathrm{CH}_{2}\right)$, 50.5 $\left(\mathrm{CH}_{2}\right), 49.7\left(\mathrm{CH}_{2}\right), 49.6\left(\mathrm{CH}_{2}\right), 48.8\left(\mathrm{CH}_{2}\right), 48.8\left(\mathrm{CH}_{2}\right)$, $48.7\left(\mathrm{CH}_{2}\right), 48.6\left(\mathrm{CH}_{2}\right)$. ESI-HR-MS (positive) $\mathrm{m} / \mathrm{z}$ calcd. for $\left[\mathrm{C}_{15} \mathrm{H}_{23} \mathrm{~N}_{4} \mathrm{O}_{2}\right]^{+}:$291.18155, found: 291.1817, $[\mathrm{M}+\mathrm{H}]^{+} ; 251$ and $207=$ fragmentations.

Compound 8. A solution of compound 7 (0.50 g, 1.73 $\mathrm{mmol}$ ) and $\mathrm{K}_{2} \mathrm{CO}_{3}$ (o.72g, $5.18 \mathrm{mmol}$, 3 equiv) in $\mathrm{CH}_{3} \mathrm{CN}$ (91 $\mathrm{mL}$ ) was stirred at $60^{\circ} \mathrm{C} 30 \mathrm{~min}$. A solution of methyl 2bromoacetate ( $0.335 \mathrm{~mL}, 3.54 \mathrm{mmol}, 2.05$ equiv) in $\mathrm{CH}_{3} \mathrm{CN}$ (91 $\mathrm{mL}$ ) was added to this solution dropwise. The reaction mixture was stirred at $60^{\circ} \mathrm{C}$ for $20 \mathrm{~h}$, cooled down to room temperature and salts were filtered off. The filtrate was evaporated to dryness and the residue was taken up in dichloromethane. Residual salts were filtered and the filtrate was evaporated to dryness. The residue was dissolved in the minimum of $\mathrm{CH}_{2} \mathrm{Cl}_{2}$ and hexane was added in large excess. After $4 \mathrm{~h}$, an oil appeared on the wall of the flask. Isolation of the supernatant and evaporation to dryness gave compound 8 (590 mg, $1.36 \mathrm{mmol}, 78 \%$, mixture of two rotamers) as a pale yellow oil. ${ }^{1} \mathrm{H}$ NMR $\left(500 \mathrm{MHz}, \mathrm{CDCl}_{3}\right) \delta$ $7.58(\mathrm{~m}, 1 \mathrm{H}, \mathrm{H} 13), 7.25-7.18(\mathrm{~m}, 1 \mathrm{H}), 7.10(\mathrm{~d}, J=6.5 \mathrm{~Hz}, 1 \mathrm{H})$, $5.92-5.76(\mathrm{~m}, 1 \mathrm{H}, \mathrm{H} 21), 5.20(\mathrm{~m}, 1 \mathrm{H}, \mathrm{H} 22 \mathrm{a}), 5.12(\mathrm{~d}, J=5.8$ $\mathrm{Hz}, \mathrm{H} 22 \mathrm{~b}), 4.56\left(\mathrm{~m}, 2 \mathrm{H}, \mathrm{CH}_{2}\right.$ pyclen), $4.50(\mathrm{~m}, 2 \mathrm{H}, \mathrm{H} 2 \mathrm{O})$, $4.03\left(\mathrm{~d}, J=4.5 \mathrm{~Hz}, 2 \mathrm{H}, \mathrm{CH}_{2}\right.$ pyclen $), 3.72-3.52(\mathrm{~m}, 11 \mathrm{H}$, $2^{*} \mathrm{OCH}_{3}+\mathrm{CH}_{2}$ pyclen), 3.40 (br s, $1 \mathrm{H}, \mathrm{CH}_{2}$ acetate), 3.26 (br $\mathrm{s}, 1 \mathrm{H}, \mathrm{CH}_{2}$ acetate), $2.69\left(\mathrm{~m}, 4 \mathrm{H}, \mathrm{CH}_{2}\right.$ pyclen), $2.61(\mathrm{br} \mathrm{s}, 1 \mathrm{H}$, $\mathrm{CH}_{2}$ pyclen), 2.48 (br s, $1 \mathrm{H}, \mathrm{CH}_{2}$ pyclen). ${ }^{13} \mathrm{C}$ NMR (125 MHz, $\mathrm{CDCl}_{3}$ ): Some $\mathrm{C}$ presents two signals because of the presence of rotamers, $\delta$ 171.6, 171.5 $(\mathrm{C}=\mathrm{O}), 157.9,157.7,156.6$, 156.4 ( $C_{1}$ and $\left.C_{11}\right), 155.8,155.5$ ( $\left.C_{19}\right), 137.6,137.4\left(C_{13}\right), 132.8$, 132.7 ( $\mathrm{C}_{21}$ ), 122.7, 122.4, 122.2, 121.6 ( $\mathrm{C}_{12}$ and $\mathrm{C}_{14}$ ), 117.2, 117.1 (C22), 65.9, 65.9 (C20), 59.6, 59.5, 55.9, 55.7, 54.5, 54.1 $\left(\mathrm{CH}_{2}\right.$ pyclen and $\left.\mathrm{C}_{1} 6, \mathrm{C}_{1} 6^{\prime}\right), 51.3,51.2\left(\mathrm{C}_{18}, \mathrm{C}_{1} 8^{\prime}\right)$, 50.9, 50.4, 50.3, 50.2, 48.9, 48.3, 46.6, 46.o ( $\mathrm{CH}_{2}$ pyclen). ESI-HR-MS (positive) $\mathrm{m} / \mathrm{z}$ calcd. for $\left[\mathrm{C}_{21} \mathrm{H}_{31} \mathrm{~N}_{4} \mathrm{O}_{6}\right]^{+}: 435.2238$, found: 
435.2234, $[\mathrm{M}+\mathrm{H}]^{+}$; calcd. for $\left[\mathrm{C}_{21} \mathrm{H}_{30} \mathrm{~N}_{4} \mathrm{NaO}_{6}\right]^{+}:$457.2058, found: 457.2055, $[\mathrm{M}+\mathrm{Na}]^{+} ; 351,363=$ fragmentations.

Compound 9. A solution of compound 8 ( $0.31 \mathrm{~g}, 0.71$ mmol) in $\mathrm{CH}_{2} \mathrm{Cl}_{2}(71 \mathrm{~mL})$ at $0^{\circ} \mathrm{C}$ was bubbled with $\mathrm{N}_{2}$ for 45 min and then warmed to room temperature before addition of $\mathrm{Pd}\left(\mathrm{PPh}_{3}\right)_{4}(0.082 \mathrm{~g}, 0.07 \mathrm{mmol}$, o.1 equiv) and phenylsilane (o.352 $\mu \mathrm{L}, 2.85 \mathrm{mmol}, 4$ equiv). The reaction mixture was stirred at room temperature for $15 \mathrm{~min}$, concentrated to $\mathrm{V}=2 \mathrm{~mL}$ and immediately purified by column chromatography on alumina gel (eluent: $\mathrm{CH}_{2} \mathrm{Cl}_{2} / \mathrm{MeOH} / \mathrm{Et}_{3} \mathrm{~N}$ 100/0/1 to 100/1/1) to give compound 9 (o.16 g, $0.46 \mathrm{mmol}, 64 \%)$ as a brown oil. ${ }^{1} \mathrm{H}$ NMR ( $500 \mathrm{MHz}$, $\left.\mathrm{CDCl}_{3}\right) \delta 7.50(\mathrm{t}, J=7.6 \mathrm{~Hz}, 1 \mathrm{H}, \mathrm{H13}), 7.01(\mathrm{~d}, J=7.6 \mathrm{~Hz}, 1 \mathrm{H}$, $\mathrm{H} 12), 6.96(\mathrm{~d}, J=7.6 \mathrm{~Hz}, 1 \mathrm{H}, \mathrm{H} 14), 4.02(\mathrm{~s}, 2 \mathrm{H}, \mathrm{H} 1 \mathrm{O}), 3.90(\mathrm{~s}$, $2 \mathrm{H}, \mathrm{Hz}), 3.57\left(\mathrm{~s}, 3 \mathrm{H}, \mathrm{OCH}_{3}\right), 3.55\left(\mathrm{~s}, 3 \mathrm{H}, \mathrm{OCH}_{3}\right), 3.45(\mathrm{~s}, 2 \mathrm{H}$, H16), $\left.3.31\left(\mathrm{~s}, 2 \mathrm{H}, \mathrm{H}_{16}\right)^{\prime}\right), 2.95(\mathrm{t}, J=6.1 \mathrm{~Hz}, 2 \mathrm{H}, \mathrm{H} 4), 2.75-$ $2.67(\mathrm{~m}, 2 \mathrm{H}, \mathrm{H} 7), 2.63(\mathrm{~m}, 2 \mathrm{H}, \mathrm{H} 8), 2.28(\mathrm{t}, J=6.1 \mathrm{~Hz}, 2 \mathrm{H}$, $\left.\mathrm{H}_{5}\right) .{ }^{13} \mathrm{C}$ NMR (75 MHz, $\left.\mathrm{CDCl}_{3}\right) \delta$ 172.1, $171.7(\mathrm{C}=\mathrm{O}), 158.6$, 158.4 ( $\left.\mathrm{C}_{1}, \mathrm{C}_{11}\right), 136.8$ ( $\left.\mathrm{C}_{13}\right), 121.5,121.4$ ( $\mathrm{C}_{14}$ and $\left.\mathrm{C}_{12}\right), 61.2$ $\left.\left(\mathrm{C}_{2}\right), 58.2\left(\mathrm{C}_{1} 6\right), 55.5\left(\mathrm{C}_{16}\right)^{\prime}\right), 54.6\left(\mathrm{C}_{4}\right), 53.8\left(\mathrm{C}_{7}\right), 52.6\left(\mathrm{C}_{10}\right)$, $51.5\left(\mathrm{OCH}_{3}\right), 51.3\left(\mathrm{OCH}_{3}\right), 49.1\left(\mathrm{C}_{5}\right), 44.4(\mathrm{C} 8)$. ESI-HR-MS (positive) $\mathrm{m} / \mathrm{z}$ calcd. for $\left[\mathrm{C}_{17} \mathrm{H}_{27} \mathrm{~N}_{4} \mathrm{O}_{4}\right]^{+}: 351.2027$, found: 351.2026, $[\mathrm{M}+\mathrm{H}]^{+}$; calcd. for $\left[\mathrm{C}_{17} \mathrm{H}_{26} \mathrm{~N}_{4} \mathrm{NaO}_{4}\right]^{+}: 373.1846$, found: 373.1843, $[\mathrm{M}+\mathrm{Na}]^{+}$; calcd. for $\left[\mathrm{C}_{17} \mathrm{H}_{28} \mathrm{~N}_{4} \mathrm{O}_{4}\right]^{2+}$ : 176.1049, found: $176.1047,[\mathrm{M}+2 \mathrm{H}]^{2+}$.

3,6-PC2A. A solution of compound 9 (o.133 g, $0.38 \mathrm{mmol}$ ) in $3 \mathrm{M} \mathrm{HCl}(5.4 \mathrm{~mL})$ was stirred at $100^{\circ} \mathrm{C}$ for $23 \mathrm{~h}$ and then cooled down to room temperature before addition of acetone in large excess. The white precipitate was filtered on cotton and washed several times with acetone, then dissolved in water. Evaporation of water gave compound 3,6PC2A (o.123 g, $0.28 \mathrm{mmol}, 75 \%)$ as a yellow oil. ${ }^{1} \mathrm{H}$ NMR $\left(500 \mathrm{MHz}, \mathrm{D}_{2} \mathrm{O}\right) \delta 7.89(\mathrm{t}, J=7.8 \mathrm{~Hz}, \mathrm{1H}, \mathrm{H13}), 7.41(\mathrm{~d}, J=$ $7.8 \mathrm{~Hz}, 1 \mathrm{H}, \mathrm{H} 12$ ), $7.37(\mathrm{~d}, J=7.8 \mathrm{~Hz}, 1 \mathrm{H}, \mathrm{H} 14$ ), 4.79 (peak hidden under $\left.\mathrm{D}_{2} \mathrm{O}, 2 \mathrm{H}, \mathrm{H} 2\right), 4.60(\mathrm{~m}, 2 \mathrm{H}, \mathrm{H} 1 \mathrm{O}), 4.36(\mathrm{~s}, 2 \mathrm{H}$, H.6), 3.54 (s, 2H, H16), 3.50 (t, $\left.J=5.2 \mathrm{~Hz}, 2 \mathrm{H}, \mathrm{H}_{4}\right), 3.21$ (br s, $2 \mathrm{H}, \mathrm{H} 8), 2.94$ (br s, $\left.2 \mathrm{H}, \mathrm{H}_{5}\right), 2.77$ (br s, $\left.2 \mathrm{H}, \mathrm{H}_{7}\right) .{ }^{13} \mathrm{C}$ NMR $\left(125 \mathrm{MHz}, \mathrm{D}_{2} \mathrm{O}\right) \delta$ 177.9, $171.1(\mathrm{C}=\mathrm{O})$, $152.2\left(\mathrm{C}_{11}\right), 151.6\left(\mathrm{C}_{1}\right)$, $142.8\left(\mathrm{C}_{13}\right), 125.6\left(\mathrm{C}_{12}\right), 124.8\left(\mathrm{C}_{14}\right), 62.5\left(\mathrm{C}_{2}\right), 58.5\left(\mathrm{C}_{16}\right)$, $57.9\left(C_{4}\right.$ and $\left.C_{16}{ }^{\prime}\right), 54.6\left(C_{7}\right)$, 53.0 ( $\left.C_{10}\right), 52.5\left(C_{5}\right), 48.5$ (C8). ESI-HR-MS (positive) $\mathrm{m} / \mathrm{z}$ calcd. for $\left[\mathrm{C}_{15} \mathrm{H}_{23} \mathrm{~N}_{4} \mathrm{O}_{4}\right]^{+}$: 323.1714, found: 323.1714, $[\mathrm{M}+\mathrm{H}]^{+}$; calcd. for $\left[\mathrm{C}_{15} \mathrm{H}_{24} \mathrm{~N}_{4} \mathrm{O}_{4}\right]^{2+}$ : 162.0893, found: $162.0889,[\mathrm{M}+2 \mathrm{H}]^{2+}$.

Thermodynamic Stability Studies. Metal stock solutions were prepared from the highest analytical grade chemicals, and their concentrations were determined by complexometric titration with standardized $\mathrm{Na}_{2} \mathrm{H}_{2}$ EDTA and eriochrome black $\mathrm{T}$ indicator in the presence of ascorbic acid and potassium hydrogen tartrate for $\mathrm{MnCl}_{2}$, murexide indicator for $\mathrm{CaCl}_{2}$ and $\mathrm{CuCl}_{2}$, eriochrome black $\mathrm{T}$ for $\mathrm{MgCl}_{2}$ and xylenol orange in the presence of hexamethylenetetramine for the solution of $\mathrm{ZnCl}_{2}$. The concentration of the ligand stock solution was determined by $\mathrm{pH}-$ potentiometric titrations. For determining the protonation constants of the ligand, $\mathrm{pH}$ potentiometric titrations were carried out with $0.15 \mathrm{M} \mathrm{NaOH}$, using $0.002 \mathrm{M}$ ligand solutions. The ionic strength was set to $0.15 \mathrm{M}$ by using $\mathrm{NaCl}$.
The titrated samples (starting volume of $6 \mathrm{~mL}$ ) were stirred mechanically and thermostated at $25^{\circ} \mathrm{C}$ by a circulating water bath $\left( \pm 0.1{ }^{\circ} \mathrm{C}\right)$. The protonation constants of the ligand $\left(\log K_{\mathrm{i}}^{\mathrm{H}}\right)$ are defined as follows:

$$
K_{i}^{\mathrm{H}}=\frac{\left[\mathrm{H}_{i} \mathrm{~L}\right]}{\left[\mathrm{H}_{i-1} \mathrm{~L}\right]\left[\mathrm{H}^{+}\right]}
$$

where $i=1,2, \ldots, 4$ and $\left[\mathrm{H}_{\mathrm{i}-1} \mathrm{~L}\right]$ and $\left[\mathrm{H}^{+}\right]$are the equilibrium concentrations of the ligand $(i=1)$, its protonated forms $(i$ $=2, \ldots, 4)$ and hydrogen ion, respectively. To avoid the effect of $\mathrm{CO}_{2}, \mathrm{~N}_{2}$ gas was bubbled through the solutions during the titrations process. The $\mathrm{pH}$-potentiometric titrations were performed with a Metrohm 785 DMP Titrino titration workstation with the use of a Metrohm 6.0234.100 combined electrode in the $\mathrm{pH}$ range of 1.75-11.8. For the calibration of the $\mathrm{pH}$ meter, $\mathrm{KH}$-phtalate $(\mathrm{pH}=4.005)$ and borax $(\mathrm{pH}=9.177)$ buffers were used, and the $\mathrm{H}^{+}$concentrations were calculated from the measured $\mathrm{pH}$ values by applying the method proposed by Irving et al..$^{1} \mathrm{~A}$ solution of approximately $0.01 \mathrm{M} \mathrm{HCl}$ was titrated with a $0.15 \mathrm{M}$ $\mathrm{NaOH}$ solution $(0.15 \mathrm{M} \mathrm{NaCl})$, and the differences between the measured and calculated $\mathrm{pH}$ values (for the points with $\mathrm{pH}<2.4$ ) were used to calculate the $\left[\mathrm{H}^{+}\right]$from the $\mathrm{pH}$ values measured in the titration experiments. The measured points with $\mathrm{pH}>11.0$ of the acid-base titration were used to calculate the ionic product of water which was found to be 13.847 under our experimental conditions. For the calculation of the equilibrium constants, the PSEQUAD program was used..$^{52}$ The stability constants of the metal complexes (except for $\mathrm{Cu}(\mathrm{II})$ ) were determined using the direct $\mathrm{pH}$-potentiometric method by titrating samples with 1:1 metal-to-ligand ratios (the number of fitted data pairs were between 150-200), allowing $1 \mathrm{~min}$ for the sample equilibration to occur. The stability constants of the $\mathrm{Cu}$ (II) complexes was too high to be determined by $\mathrm{pH}$-potentiometry, hence a direct UV-vis spectrophotometric method was used. The spectrophotometric measurements were performed with a JASCO V-77o UV-vis-NIR spectrophotometer at $25^{\circ} \mathrm{C}$, using semimicro $1.0 \mathrm{~cm}$ cells. For the determination of the stability constants the absorbance was measured at 8 different acid concentrations (falling in the acid concentration range of $0.11-1.00 \mathrm{M}$ ) at 17 wavelengths between 640 and $800 \mathrm{~nm}$ (the concentration of the complex was $3.0 \mathrm{mM}$ ). A pH-potentiometric titration of the $\mathrm{Cu}(\mathrm{II})$ complexes was also performed in the $\mathrm{pH}$ range 1.75-11.85 with a starting volume of $6 \mathrm{~mL}, \mathrm{C}_{\mathrm{Cu}(\mathrm{II})}=\mathrm{C}_{\mathrm{PC}_{2} \mathrm{As}}=2.0 \mathrm{mM}$ and these data were treated simultaneously with those obtained the UV-vis-NIR spectrophotometric measurements.

Kinetic Studies. The inertness of the $\left.\left[\mathrm{Mn}_{3}, 6-\mathrm{PC}_{2} \mathrm{~A}\right)\right]$ and $\left[\mathrm{Mn}\left(3,9-\mathbf{P C}_{2} \mathrm{~A}\right)\right]$ complexes were studied by various methods. The transmetallation reaction initiated by with $\mathrm{Zn}(\mathrm{II})$ ions was monitored by measuring the $T_{2}$ relaxation times as a function of time at $\mathrm{pH}=6.0$, set by $50 \mathrm{mM} 2-(\mathrm{N}$-morpholino)ethanesulfonic acid (MES) buffer in the presence of 25 equivalents of $\mathrm{Zn}$ (II) ions at $37^{\circ} \mathrm{C}$. These conditions were used recently by $\mathrm{P}$. Caravan et al. and employed here to obtain to have data that can be directly compared to $\left[\mathrm{Mn}\left(\mathrm{PyC}_{3} \mathrm{~A}\right)\right]$ we have adopted the same method. ${ }^{10}$ 
Metal exchange reactions occurring between the complex and $\mathrm{Cu}(\mathrm{II})$ (in the presence of 10-40-fold excess to ensure pseudo-first-order conditions) was investigated at 25 ${ }^{\circ} \mathrm{C}$ and $0.15 \mathrm{M} \mathrm{NaCl}$ ionic strength by using JASCO V-770 UV-vis-NIR spectrophotometer at $290 \mathrm{~nm}$. The concentration of the complexes were set to 0.294 and $0.398 \mathrm{mM}$ for the $\mathrm{Mn}(\mathrm{II})$ complexes of 3,6- and 3,9-PC2A, respectively, while the concentration of $\mathrm{CuCl}_{2}$ was as follows: 3.06, 6.12, 9.18 and $12.20 \mathrm{mM}$ for $\left[\mathrm{Mn}\left(3,6-\mathrm{PC}_{2} \mathrm{~A}\right)\right]$ and 3.98, 7.96, 11.94 and $15.92 \mathrm{mM}$ for $\left[\mathrm{Mn}\left(3,9-\mathbf{P C}_{2} \mathrm{~A}\right)\right]$. All the kinetic studies were performed by using a noncoordinating buffer, $N, N$ ' dimethyl piperazine (DMP, $\log K_{2}{ }^{\mathrm{H}}=4.19$ ) at $0.05 \mathrm{M}$ concentration to maintain constant $\mathrm{pH}$ in the samples in the $\mathrm{pH}$ range of 3.55-4.75 and 3.98-5.02). The values of the pseudo-first-order rate constants $\left(k_{\text {obs }}\right)$ were determined using the following equation: $A_{\mathrm{t}}=\left(A_{\mathrm{r}}-A_{\mathrm{p}}\right) \mathrm{e}^{-k \text { obs } \times \mathrm{t}}+A_{\mathrm{v}}$, where $A_{\mathrm{t}}$ is the absorbance at time $\mathrm{t}, A_{\mathrm{r}}$ is the absorbance of the reactants, $A_{\mathrm{p}}$ is the absorbance of the products.

Serum stability of the $\mathrm{Mn}$ (II) complexes was studied by following the $r_{\mathrm{p}}$ relaxivities of the complexes over time using 1.0 $\mathrm{mM}$ solutions in Seronorm ${ }^{\mathrm{TM}}$ (Seronorm $=$ commercially available lyophilized human blood serum, Sero, Stasjonsveien, Norway) at $\mathrm{pH}=7.39$ and $25{ }^{\circ} \mathrm{C}$.

Relaxation properties. The ${ }^{1} \mathrm{H}$ longitudinal $\left(T_{1}\right)$ and transverse $\left(T_{2}\right)$ relaxation times were measured by using Bruker Minispec MQ-20 and MQ-6o NMR Analyzers. The temperature of the sample holder was set $25.0( \pm 0.2){ }^{\circ} \mathrm{C}$ and controlled with a circulating water bath thermostat. The $r_{1 \mathrm{p}}$ values for the investigated complexes were determined by means of inversion recovery method $\left(180^{\circ}-\tau-90^{\circ}\right)$, averaging 4-6 data points obtained at 12 different $\tau$ delay times, while $r_{2 \mathrm{p}}$ data were collected by using Carl-PurcellMeiboom-Gill (CPMG) spin-echo pulse sequence. Relaxivities were determined by published procedures in samples of 0.3-0.4 $\mathrm{mL}$ volume. $\mathrm{pH}$ were either set by using a $0.05 \mathrm{M}$ 4-(2-hydroxyethyl)-1-piperazine-ethanesulfonic acid (HEPES) buffer ( $\mathrm{pH}=7.4$ ) or monitored ( $\mathrm{pH}$-profiles) using a Metrohm $827 \mathrm{pH}$ lab $\mathrm{pH}$-meter and a Metrohm 6.0234.100 combined electrode in the $\mathrm{pH}$ range of 1.75-11.8.

${ }^{17} \mathrm{O}$ NMR measurements. Variable-temperature ${ }^{17} \mathrm{O}$ NMR measurements of aqueous solutions of the complexes $\left(c_{\mathrm{MnL}}=4.02 \mathrm{mmol} / \mathrm{kg}, \mathrm{pH} 6.86\right.$, and $c_{\mathrm{MnL}}=3.99 \mathrm{mmol} / \mathrm{kg}$, $\mathrm{pH} 8.83$, respectively) were performed on a Bruker Avance III $400 \mathrm{MHz}$ spectrometer $(9.4 \mathrm{~T}, 54.2 \mathrm{MHz})$ in the temperature range $\mathrm{o}-85^{\circ} \mathrm{C}$. The temperature was calculated after calibration with ethylene glycol and MeOH.53 Acidified water $\left(\mathrm{HClO}_{4}, \mathrm{pH}=3.3\right)$ was used as diamagnetic reference. Previous studies showed that an acidified water reference or the corresponding $\mathrm{Zn}^{2+}$ complex at identical concentration and $\mathrm{pH}$ as the paramagnetic $\mathrm{Mn}$ (II) sample gave identical results. Erreur! Signet non défini. The ${ }^{17} \mathrm{O}$ transverse $\left(T_{2}\right)$ relaxations times were obtained by the Carl-PurcellMeiboom-Gill spin-echo technique.54 To eliminate the susceptibility contributions to the chemical shift the sample was placed in a glass sphere fixed in a $10 \mathrm{~mm}$ NMR tube. ${ }^{55}$ To improve sensitivity, the amount of ${ }^{17} \mathrm{O}$ was enriched by adding $\mathrm{H}_{2}{ }^{17} \mathrm{O}$ (10 $\% \mathrm{H}_{2}{ }^{17} \mathrm{O}$, CortecNet) to achieve approximately $1 \%{ }^{17} \mathrm{O}$ content in the samples.

The ${ }^{17} \mathrm{O}$ NMR data were analyzed according to the Swift Connick equations. ${ }^{6}$ The least-squares fit of the data were performed using Visualizeur/Optimiseur ${ }^{57}$ running on a MATLAB 8.3.o (R2014a) platform.

Cyclic voltammetry. Cyclic voltammetry experiments were carried out using a 797 VA Computrace potentiostat/galvanostat from Metrohm (Herisau, Switzerland) equipped with a typical three electrode cell. A glassy carbon rotating disk electrode (stirring rate of $2000 \mathrm{rpm}$ ) was employed as the working electrode, while the counter electrode was a platinum rod. Potentials were recorded using a $\mathrm{Ag} / \mathrm{AgCl}$ reference electrode filled with $3 \mathrm{~mol} \mathrm{~L}^{-1} \mathrm{KCl}$. Aqueous solutions of the complexes in $0.15 \mathrm{M} \mathrm{NaCl}$ were purged with high purity (99.999\%) nitrogen over 30 seconds before recording the cyclic voltammograms. Sweep rates from 5 and up to $500 \mathrm{mV} \mathrm{s}^{-11}$ were used. The starting and end potentials were set to o.o $\mathrm{V}$, while the first vertex potential was +1.0 V.

DFT calculations. Density functional theory calculations were performed with the Gaussian 16 program package (version B.o1).58 Geometry optimizations of the $\left[\mathrm{Mn}\left(3,6-\mathrm{PC}_{2} \mathrm{~A}\right)\left(\mathrm{H}_{2} \mathrm{O}\right)\right] \cdot 2 \mathrm{H}_{2} \mathrm{O}, \quad$ and $\quad[\mathrm{Mn}(3,9-$ PC2A) $\left.\left(\mathrm{H}_{2} \mathrm{O}\right)\right] \cdot 2 \mathrm{H}_{2} \mathrm{O}$ systems were carried out with the M11 functional,59 which belongs to the family of hybrid-meta GGA functionals (Supporting Information Tables $\mathrm{S}_{1}-\mathrm{S}_{3}$ ). The def2-TZVPP basis set was used throughout. ${ }^{60}$ Bulk solvent effects (water) were included with the integral equation formalism implementation of the polarizable continuum model (IEFPCM). ${ }^{61}$ Frequency calculations were conducted to confirm the nature of the optimized geometries as true energy minima.

SOD activity measurements. Xanthine, xanthine oxidase $(0.5 \mathrm{U} / \mathrm{mg})$ and nitro blue tetrazolium chloride (NBT) were purchased from Sigma-Aldrich. In order to study the SOD activity of the Mn(II) complexes of 3,6-, 3,9-PC2A and PCTA, the xanthine/xanthine oxidase system was used to generate the superoxide anion radical $\left(\mathrm{O}_{2}{ }^{\bullet-}\right)$. The radical reacts with para-nitro blue tetrazolium chloride (NBT) to produce diformazan with a characteristic molar absorptivity at $560 \mathrm{~nm}$. The formation of diformazan can readily be followed by UV-vis spectroscopy. The addition of the $\mathrm{Mn}$ (II) complexes to this system prevents the reduction of NBT. The assay was carried out in phosphate buffer (0.05 $\mathrm{M})$ containing NBT $(45 \mu \mathrm{M})$ and xanthine $(200 \mu \mathrm{M})$. The reaction was initiated by adding an appropriate amount of xanthine oxidase to produce around $0.020-0.028 \mathrm{~min}^{-1}$ rate of the absorbance change at $560 \mathrm{~nm}$. First, the reaction was monitored in a blank sample (without the addition of any Mn(II) complex) for 3-4 min. Then the Mn(II) complex was added to the same sample and the absorbance was monitored for further $4 \mathrm{~min}$. The corresponding rates were obtained by fitting the experimental data to a straight line. The SOD activity was expressed as the $\mathrm{IC}_{50}$ value, which 
was converted into rate constants as described elsewhere in detail (Supporting information Table $\mathrm{S}_{4}$ ). ${ }^{62}$

\section{ASSOCIATED CONTENT}

\section{Supporting Information}

The supporting Information is available:

Synthesis of 2, 3, 5, 6 and [Mn(3,6-PC2A)], NMR and HRMS, HPLC traces, UV-Vis titrations, voltammograms, DFT data and the results of SOD activity studies (PDF).

\section{AUTHOR INFORMATION}

\section{Corresponding Authors}

*E-mail: carlos.platas.iglesias@udc.es (C. P.-I.)

*E-mail: raphael.tripier@univ-brest.fr (R. T.)

*E-mail: gyula.tircso@science.unideb.hu (Gy. T.)

\section{Author Contributions}

The manuscript was written through contributions of all authors. All authors have given approval to the final version of the manuscript.

\section{ACKNOWLEDGMENT}

G. T., F. K. K., I. T. and N. L. are grateful for the financial support of the Hungarian National Research, Development and Innovation Office (NKFIH K-120224, 128201, 134694 and PD128326 projects) for their financial support. Gy. T. and C. P.-I. gratefully acknowledge the COST Action CA15209 "European Network on NMR Relaxometry" and the bilateral HungarianSpanish science and technology cooperation program (20192.1.11-TÉT-2019-00o84). R.T. acknowledges the Ministère de l'Enseignement Supérieur et de la Recherche, the Centre National de la Recherche Scientifique and the "Service Commun" of NMR facilities of the University of Brest. Gy.T. acknowledges the University of Brest for his invited Professor position in 2014. D. E.-G. and C. P.-I. thank Ministerio de Economía y Competitividad (CTQ2016-76756-P) and Xunta de Galicia (ED431B 2020/52) for generous financial support. The authors are indebted to Centro de Supercomputación de Galicia (CESGA) for providing the computer facilities. . E.T. acknowledges financial support from the French National Research Agency (grant ANR-18-CE18-ooo8).

\section{REFERENCES}

(1) (a) Gupta, A.; Caravan, P.; Price, W. S.; Platas-Iglesias, C.; Gale, E. M. Applications for Transition-Metal Chemistry in Contrast-Enhanced Magnetic Resonance Imaging. Inorg. Chem. 2020, 59, 6648-6678; (b) Botta, M.; Carniato, F.; Esteban-Gómez, D.; Platas-Iglesias, C.; Tei, L. Mn(II) compounds as an alternative to Gd-based MRI probes. Future Med. Chem. 2019, 11, 1461-1483.

(2) (a) Drahos, B.; Lukes, I.; Tóth, E. Manganese(II) Complexes as Potential Contrast Agents for MRI. Eur. J. Inorg. Chem. 2012, 2012, 1975-1986. (b) Pan, D.; Schmieder, A. H.; Wickline, S. A.; Lanza, G. M. Manganese-Based MRI Contrast Agents: Past, Present, and Future. Tetrahedron 2011, 67, 8431-8444.

(3) Wahsner, J.; Gale, E. M.; Rodríguez-Rodríguez, A.; Caravan, P. Chemistry of MRI Contrast Agents: Current Challenges and New Frontiers. Chem. Rev. 2019, 119, 957-1057.
(4) Rolla, G. A.; Platas-Iglesias, C.; Botta, M.; Tei, L.; Helm, L. ${ }^{1} \mathrm{H}$ and ${ }^{17} \mathrm{O}$ NMR Relaxometric and Computational Study on Macrocyclic Mn(II) Complexes. Inorg. Chem. 2o13, 52, 3268-3279.

(5) (a) Pujales-Paradela, R.; Carniato, F.; Uzal-Varela, R.; Brandariz, I.; Iglesias, E.; Platas-Iglesias, C.; Botta, M.; EstebanGómez, D. A pentadentate member of the picolinate family for $\mathrm{Mn}$ (II) complexation and an amphiphilic derivative. Dalton Trans. 2019, 48, 696-710; (b) Phukan, B.; Mukherjee, C.; Goswami, U.; Sarmah, A.; Mukherjee, S.; Sahoo, S. K.; Moi, S. C. A New Bis(aquated) High Relaxivity Mn(II) Complex as an Alternative to Gd(III)-Based MRI Contrast Agent. Inorg. Chem. 2018, 57, 2631-2638; (c) Khannam, M.; Weyhermüller, T.; Goswami, U.; Mukherjee, C. A Highly Stable L-Alanine-Based Mono(aquated) Mn(II) Complex as a $T_{1}$-Weighted MRI Contrast Agent. Dalton Trans. 2017, 46, 10426-10432.

(6) Inoue, T.; Majid, T.; Pautler, R. G. Manganese Enhanced MRI (MEMRI): Neurophysiological Applications. Rev. Neurosci. 2011, 22, 675-694.

(7) Rivera-Mancía, S.; Ríos, C.; Montes, S. Manganese accumulation in the CNS and associated pathologies. Biometals 2011, $24,811-825$.

(8) Ndiaye, D.; Sy, M.; Pallier, A.; Même, S.; de Silva, I.; Lacerda, S.; Nonat, A. M.; Charbonnière, L. J.; Tóth, É. Unprecedented Kinetic Inertness for a $\mathrm{Mn}^{2+}$-Bispidine Chelate: A Novel Structural Entry for $\mathrm{Mn}^{2+}$-Based Imaging Agents. Angew. Chem., Int. Ed. 2020, 59, 11958-11963.

(9) Kálmán, F. K.; Tircsó, G. Kinetic Inertness of the $\mathrm{Mn}^{2+}$ Complexes Formed with AAZTA and Some Open-Chain EDTA Derivatives. Inorg. Chem. 2012, 51, 10065-10067.

(10) Gale, E. M.; Atanasova, I. P.; Blasi, F.; Ay, I.; Caravan, P. A Manganese Alternative to Gadolinium for MRI Contrast. J. Am. Chem. Soc. 2015, 137, 15548-15557.

(11) Pota, K.; Garda, Z.; Kálmán, F. K.; Luis Barriada, J. L.; Esteban-Gómez, D.; Platas-Iglesias, C.; Tóth, I.; Brücher, E. Tircsó, G. Taking the Next Step Toward Inert $\mathrm{Mn}^{2+}$ Complexes of OpenChain Ligands: The Case of the Rigid PhDTA Ligand. New J. Chem. 2018, 42, 8001-8011.

(12) Erstad, D. J.; Ramsay, I. A.; Jordan, V. C.; Sojoodi, M.; Fuchs, B. C.; Tanabe, K. K.; Caravan, P.; Gale, E. M. Tumor Contrast Enhancement and Whole-Body Elimination of the Manganese-Based Magnetic Resonance Imaging Contrast Agent Mn$\mathrm{PyC}_{3}$ A. Invest. Radiol. 2019, 54, 697-703.

(13) Vanasschen, C.; Molnár, E.; Tircsó, G.; Kálmán, F. K.; Tóth, É.; Brandt, M.; Coenen, H. H.; Neumaier. B. Novel CDTAbased, Bifunctional Chelators for Stable and Inert $\mathrm{Mn}^{\mathrm{II}}$ Complexation: Synthesis and Physicochemical Characterization. Inorg. Chem. 2017, 56, 7746-776o.

(14) Wang, J.; Wang, H.; Ramsay, I. A.; Erstad, D. J.; Fuchs B. C.; Tanabe, K. K.; Caravan, P.; Gale, E. M. Manganese-Based Contrast Agents for Magnetic Resonance Imaging of Liver Tumors: Structure-Activity Relationships and Lead Candidate Evaluation. J. Med. Chem. 2018, 61, 8811-8824.

(15) (a) Baranyai, Z.; Pálinkás, Z.; Uggeri, F.; Maiocchi, A.; Aime, S.; Brücher, E. Dissociation Kinetics of Open-Chain and Macrocyclic Gadolinium(III)-Aminopolycarboxylate Complexes Related to Magnetic Resonance Imaging: Catalytic Effect of Endogenous Ligands. Chem. Eur. J. 2012, 18, 16426-16435; (b) Baranyai, Z.; Brücher, E.; Uggeri, F.; Maiocchi, A.; Tóth, I.; Andrási, M.; Gáspár, A.; Zékány, L.; Aime, S.. The Role of Equilibrium and Kinetic Properties in the Dissociation of Gd[DTPAbis(methylamide)] (Omniscan) at near to Physiological Conditions. Chem. Eur. J. 2015, 21, 4789 - 4799.

(16) Garda, Z.; Molnár, E.; Kálmán, F. K.; Botár, R.; Nagy, V.; Baranyai, Z.; Brücher, E.; Kovács, Z.; Tóth, Z.; Tircsó, G. Effect of 
the Nature of Donor Atoms on the Thermodynamic, Kinetic and Relaxation Properties of Mn(II) Complexes Formed With Some Trisubstituted 12-Membered Macrocyclic Ligands. Front. Chem. 2018, 6, 232.

(17) Drahos, B.; Kotek, J.; Hermann, P.; Lukes, I.; Tóth, É. $\mathrm{Mn}^{2+}$ Complexes with Pyridine-Containing 15-Membered Macrocycles: Thermodynamic, Kinetic, Crystallographic, and ${ }^{1} \mathrm{H} /{ }^{17} \mathrm{O}$ Relaxation Studies. Inorg. Chem. 2010, 49, 3224-3238.

(18) Garda, Z.; Forgács, A.; Do, Q. N.; Kálmán, F. K.; Timári, S.; Baranyai, Z.; Tei, L.; Tóth, I.; Kovács, Z.; Tircsó, G. Physicochemical Properties of $\mathrm{Mn}^{\mathrm{II}}$ Complexes Formed with cis- and trans-DO2A: Thermodynamic, Electrochemical and Kinetic studies. J. Inorg. Biochem. 2016, 163, 206-213.

(19) Forgács, A.; Tei, L.; Baranyai, Z.; Tóth, I.; Zékány, L.; Botta, M. A Bisamide Derivative of $\left[\mathrm{Mn}\left(1,4-\mathrm{DO}_{2} \mathrm{~A}\right)\right]$ - Solution Thermodynamic, Kinetic, and NMR Relaxometric Studies. Eur. J. Inorg. Chem. 2016, 1165-1174.

(20) Forgács, A.; Tei, L.; Baranyai, Z.; Esteban-Gómez, D.; Platas-Iglesias, C.; Botta, M. Optimising the relaxivities of $\mathrm{Mn}^{2+}$ complexes by targeting human serum albumin (HSA). Dalton Trans. 2017, 46, 8494-8504.

(21) Botár, R.; Molnár, E.; Trencsényi, G.; Kiss, J.; Kálmán, F. K.; Tircsó, G. Stable and Inert Mn(II)-Based and pH-Responsive Contrast Agents. J. Am. Chem. Soc. 2o2o, 142, 1662-1666.

(22) Kálmán, F. K.; Nagy, V.; Váradi, B.; Garda, Z.; Molnár, E.; Trencsényi, G.; Kiss, J.; Même, S.; Même, W.; Tóth, E.; Tircsó, G. $\mathrm{Mn}(\mathrm{II})$-Based MRI Contrast Agent Candidate for Vascular Imaging. J. Med. Chem. 2020, 63, 6057-6065.

(23) Kim, W. D.; Hrncir, D. C.; Kiefer, G. E.; Sherry, A. D. Synthesis, Crystal Structure, and Potentiometry of Pyridine-Containing Tetraaza Macrocyclic Ligands with Acetate Pendant Arms. Inorg. Chem. 1995, 34, 2225-2232.

(24) Le Fur, M.; Beyler, M.; Molnár, E.; Fougère, O.; EstebanGómez, D.; Tircsó, G.; Platas-Iglesias, C.; Lepareur, N.; Rousseaux, O.; Tripier, R. The Role of the Capping Bond Effect on Pyclen ${ }^{n a t} \mathrm{Y}^{+} / 9^{\circ} \mathrm{Y}^{3+}$ Chelates: Full Control of the Regiospecific N-functionalization Makes the Difference. Chem. Commun. 2017, 53, 95349537 .

(25) Kunz, H.; Unverzagt, C. The Allyloxycarbonyl (Aloc) Moiety-Conversion of an Unsuitable into a Valuable Amino Protecting Group for Peptide Synthesis. Angew. Chem. Int. Ed. Engl. 1984, 23, 436-437.

(26) (a) Dessolin, M.; Guillerez, M.-G.; Thieriet, N.; Guibé, F.; Loffet, A. New Allyl Group Acceptors for Palladium Catalyzed Removal of Allylic Protections and Transacylation of Allyl Carbamates. Tetrahedron Lett. 1995, 36, 5741-5744; (b) Thieriet, N.; Gomez-Martinez, P.; Guibé, F. Tandem deprotection-coupling of $\mathrm{N}^{\alpha}$-Alloc-amino acids by use of ternary systems $\mathrm{Pd}$ cat./PhSiH $3 /$ carboxy-activated amino acid. Tetrahedron Lett. 1999, 40, 2505-2508.

(27) Aime, S.; Botta, M.; Geninatti Crich, S.; Giovenzana, G. B.; Jommi, G.; Pagliarin, R.; Sisti, M. Synthesis and NMR Studies of Three Pyridine-Containing Triaza Macrocyclic Triacetate Ligands and Their Complexes with Lanthanide Ions. Inorg. Chem. 1997, 36, 2992-3000.

(28) Drahos, B.; Kotek, J.; Císarová, I.; Hermann, P.; Helm, L.; Lukeš, I.; Tóth, É. Mn ${ }^{2+}$ Complexes with 12-Membered Pyridine Based Macrocycles Bearing Carboxylate or Phosphonate Pendant Arm: Crystallographic, Thermodynamic, Kinetic, Redox, and ${ }^{1} \mathrm{H} /{ }^{17} \mathrm{O}$ Relaxation Studies. Inorg. Chem. 2011, 50, 12785-12801.

(29) Tircsó, G.; Kovács, Z.; Sherry, A. D. Equilibrium and For-

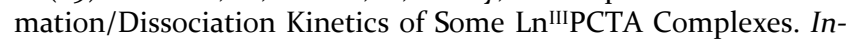
org. Chem. 2006, 45, 9269-9280.
(30) Delgado, R.; Quintino, S.; Teixeira, M.; Zhang, A. Metal Complexes of a 12-Membered Tetraaza Macrocycle Containing Pyridine and N-Carboxymethyl Groups. J. Chem. Soc., Dalton Trans. 1996, 55-63.

(31) Takacs, A.; Napolitano, R.; Purgel, M.; Benyei, A. C.; Zekany, L.; Brucher, E.; Tóth, I.; Baranyai, Z.; Aime, S. Solution Structures, Stabilities, Kinetics, and Dynamics of $\mathrm{DO}_{3} \mathrm{~A}$ and $\mathrm{DO}_{3} \mathrm{~A}-$ Sulphonamide Complexes. Inorg. Chem. 2014, 53, 2858-2872.

(32) Gündüz, S.; Vibhute, S.; Botár, R.; Kálmán, F. K.; Tóth, I.; Tircsó, G.; Regueiro-Figueroa, M.; Esteban-Gómez, D.; PlatasIglesias, C.; Angelovski, G. Coordination Properties of GdDO3ABased Model Compounds of Bioresponsive MRI Contrast Agents. Inorg. Chem. 2018, 57, 5973-5986.

(33) Bianchi, A.; Calabi, L.; Giorgi, C.; Losi, P.; Mariani, P.; Palano, D.; Paoli, P.; Rossi, P.; Valtancoli, B. Thermodynamic and structural aspects of manganese(II) complexes with polyaminopolycarboxylic ligands based upon 1,4,7,10-tetraazacyclododecane (cyclen). Crystal structure of dimeric $[\mathrm{MnL}]_{2} \cdot 2 \mathrm{CH}_{3} \mathrm{OH}$ containing the new ligand 1,4,7,10-tetraazacyclododecane-1,4-diacetate. $J$. Chem. Soc., Dalton Trans. 2001, 917-922.

(34) Esteban-Gómez, D.; Cassino, C.; Botta, M.; Platas-Iglesias, C. ${ }^{17} \mathrm{O}$ and ${ }^{~} \mathrm{H}$ Relaxometric and DFT Study of Hyperfine Coupling Constants in $\left[\mathrm{Mn}\left(\mathrm{H}_{2} \mathrm{O}\right)_{6}\right]^{2+}$. RSC Adv. 2014, 4, 7094-7103.

(35) Patinec, V.; Rolla, G. A.; Botta, M.; Tripier, R.; EstebanGómez, D.; Platas-Iglesias, C. Hyperfine Coupling Constants on Inner-Sphere Water Molecules of a Triazacyclononane-based Mn(II) Complex and Related Systems Relevant as MRI Contrast Agents. Inorg. Chem. 2013, 52, 11173-11184.

(36) Wen, J.; Geng, Z.; Yin, Y.; Wang, Z. A Mononuclear Mn²+ Complex Based on a Novel tris-(ethyl acetate) Pendant-Armed Tetraazamacrocycle: Effect of Pyridine on Self-Assembly and Weak Interactions. Inorg. Chem. Commun. 2012, 21, 16-20.

(37) (a) Le Fur, M.; Molnár, E.; Beyler, M.; Fougere, O.; Esteban-Gómez, D.; Rousseaux, O.; Tripier, R.; Tircsó, G.; PlatasIglesias, $\mathrm{C}$. Expanding the Family of Pyclen-Based Ligands Bearing Pendant Picolinate Arms for Lanthanide Complexation. Inorg. Chem. 2018, 57, 6932-6945; (b) Le Fur, M.; Molnár, E.; Beyler, Kálmán, F. K.; Fougère, O.; Esteban-Gómez, D.; Rousseaux, O.; Tripier, R.; Tircsó, G.; Platas-Iglesias, C. A Coordination Chemistry Approach to Fine-Tune the Physicochemical Parameters of Lanthanide Complexes Relevant to Medical Applications. Chem. Eur. J. 2018, 24, 3127-3131.

(38) Bader, R. F. W.; Carroll, M. T.; Cheeseman, J. R.; Chang, C. Properties of Atoms in Molecules: Atomic Volumes. J. Am. Chem. Soc. 1987, 109, 7968-7979.

(39) (a) Fanali, G.; Cao, Y.; Ascenzi, P.; Fasano, M. Mn(II) Binding to Human Serum Albumin: A ${ }^{1} \mathrm{H}-\mathrm{NMR}$ Relaxometric Study. J. Inorg. Biochem. 2012, 117, 198-203; (b) Aime, S.; Canton, S.; Crich, S. G.; Terreno, E. ${ }^{1} \mathrm{H}$ and ${ }^{17} \mathrm{O}$ Relaxometric Investigations of the Binding of $\mathrm{Mn}(\mathrm{II})$ ion to Human Serum Albumin. Magn. Reson. Chem. 2002, 40, 41-48.

(40) Caravan, P.; Farrar, C. T.; Frullano, L.; Uppal, R. Influence of Molecular Parameters and Increasing Magnetic Field Strength on Relaxivity of Gadolinium- and Manganese-Based T1 contrast agents. Contrast Media Mol. Imaging 2009, 4, 89-100.

(41) Maigut, J.; Meier, R.; Zahl, A.; van Eldik, R. Effect of Chelate Dynamics on Water Exchange Reactions of Paramagnetic Aminopolycarboxylate Complexes. Inorg. Chem. 20o8, 47, 57025719.

(42) Harley, S. J.; Ohlin, C. A.; Casey, W. H. Geochemical Kinetics via the Swift-Connick Equations and Solution NMR. Geochim. Cosmochim. Acta 2011, 75, 3711-3725. 
(43) Gale, E. M.; Zhu, J.; Caravan, P. Direct Measurement of the Mn(II) Hydration State in Metal Complexes and Metalloproteins through ${ }^{17} \mathrm{O}$ NMR Line Widths. J. Am. Chem. Soc. 2013, 135, 49, $18600-18608$.

(44) Loving, G. S.; Mukherjee, S.; Caravan, P.; Redox-Activated Manganese-Based MR Contrast Agent. J. Am. Chem. Soc. 2013, 135, 4620-4623.

(45) Forgács, A.; Regueiro-Figueroa, M.; Barriada, J. L.; Esteban-Gómez,D.; de Blas, A.; Rodríguez-Blas, T.; Botta, M.; Platas-Iglesias, C. Mono-, Bi- , and Trinuclear Bis-Hydrated $\mathrm{Mn}^{2+}$ Complexes as Potential MRI Contrast Agents. Inorg. Chem. 2015 , 54, 9576-9587.

(46) Ukeda, H.; Kawana, D.; Maeda, S.; Sawamura, M. Spectrophotometric Assay for Superoxide Dismutase Based on the Reduction of Highly Water-Solube Tetrazolium Salts by XanthineXanthine Oxidase. Biosci. Biotechnol. Biochem. 1999, 63, 485-488.

(47) Fisher, A. E. O.; Naughton, D. P. Metal Ion Chelating Peptides with Superoxide Dismutase Activity. Biomed. Pharmacother. 2005, 59, 158-162.

(48) Deroche, A.; Morgenstern-Badarau, I.; Cesario, M.; Guilhem, J.; Keita, B.; Nadjo, L.; Houée-Levin, C. A Seven-Coordinate Manganese(II) Complex Formed with a Single Tripodal Heptadentate Ligand as a New Superoxide Scavenger. J. Am. Chem. Soc. 1996, 118, 4567-4573.

(49) (a) Bonetta, R. Potential Therapeutic Applications of MnSODs and SOD-Mimetics. Chem. Eur. J. 2018, 24, 5032-5041; (b) Aston, K.; Rath, N.; Naik, A.; Slomczynska, U.; Schall, O. F.; Riley, D. P. Computer-Aided Design (CAD) of Mn(II) Complexes: Superoxide Dismutase Mimetics with Catalytic Activity Exceeding the Native Enzyme. Inorg. Chem. 2001, 40, 1779-1789.

(50) (a) Bao, J.; Zhang, Z.; Tang, R.; Han, H.; Yang, Z. Synthesis and fluorescence properties of $\mathrm{Tb}$ (III) complex with a novelaromatic carboxylic acid (L) as well as spectroscopic studies on the interaction between $\mathrm{Tb}$ (III) complex and bovine serum albumin. J. Lumin. 2013, 136, 68-74; (b) Su, H.; Wu, C.; Zhu, J.; Miao, T.; Wang, D.; Xia, C.; Zhao, X.; Gong, Q.; Song, B.; Ai, H. Rigid $\mathrm{Mn}(\mathrm{II})$ Chelate as Efficient MRI Contrast Agent for Vascular Imaging. Dalton Trans. 2012, 41, 14480-14483.

(51) Irving, H. M.; Miles, M. G.; Pettit, L. A Study of Some Problems in Determining the Stoichiometric Proton Dissociation Constants of Complexes by Potentiometric Titrations Using a Glass Electrode. Anal. Chim. Acta 1967, 38, 475-488.

(52) Zekany L., Nagypal I. PSEQUAD, in Computational Methods for the Determination of Formation Constants. Modern Inorganic Chemistry. Leggett D. J. (Ed), Springer, Boston, 1985.

(53) Raiford, D. S.; Fisk, C. L.; Becker, E. D. Calibration of Methanol and Ethylene Glycol Nuclear Magnetic Resonance Thermometers. Anal. Chem. 1979, 51, 2050-2051.

(54) Meiboom, S.; Gill, D. Modified Spin-Echo Method for Measuring Nuclear Relaxation Times. Rev. Sci. Instrum. 1958, 29, 688-691.
(55) Hugi, A. D.; Helm, L.; Merbach, A. E. Water Exchange on Hexaaquavanadium(III): a Variable-Temperature and Variable-Pressure ${ }^{17} \mathrm{O}-\mathrm{NMR}$ Study at 1.4 and 4.7 Tesla. Helv. Chim. Acta $1985,68,508-521$.

(56) (a) Swift, T. J.; Connick, R. E. NMR-Relaxation Mechanisms of $\mathrm{O}^{17}$ in Aqueous Solutions of Paramagnetic Cations and the Lifetime of Water Molecules in the First Coordination Sphere. J. Chem. Phys. 1962, 37, 307-320. (b) Swift, T. J.; Connick, R. E. NMR-Relaxation Mechanisms of ${ }^{17} \mathrm{O}$ in Aqueous Solutions of Paramagnetic Cations and the Lifetime of Water Molecules in the First Coordination Sphere. J. Chem. Phys. 1964, 41, 2553.

(57) (a) Yerly, F. VISUALISEUR 2.3.5; Lausanne, Switzerland, 1999; (b) Yerly, F. OPTIMISEUR 2.3.5; Lausanne, Switzerland, 1999.

(58) Gaussian 16, Revision C.o1, Frisch, M. J.; Trucks, G. W.; Schlegel, H. B.; Scuseria, G. E.; Robb, M. A.; Cheeseman, J. R.; Scalmani, G.; Barone, V.; Petersson, G. A.; Nakatsuji, H.; Li, X.; Caricato, M.; Marenich, A. V.; Bloino, J.; Janesko, B. G.; Gomperts, R.; Mennucci, B.; Hratchian, H. P.; Ortiz, J. V.; Izmaylov, A. F.; Sonnenberg, J. L.; Williams-Young, D.; Ding, F.; Lipparini, F.; Egidi, F.; Goings, J.; Peng, B.; Petrone, A.; Henderson, T.; Ranasinghe, D.; Zakrzewski, V. G.; Gao, J.; Rega, N.; Zheng, G.; Liang, W.; Hada, M.; Ehara, M.; Toyota, K.; Fukuda, R.; Hasegawa, J.; Ishida, M.; Nakajima, T.; Honda, Y.; Kitao, O.; Nakai, H.; Vreven, T.; Throssell, K.; Montgomery, J. A., Jr.; Peralta, J. E.; Ogliaro, F.; Bearpark, M. J.; Heyd, J. J.; Brothers, E. N.; Kudin, K. N.; Staroverov, V. N.; Keith, T. A.; Kobayashi, R.; Normand, J.; Raghavachari, K.; Rendell, A. P.; Burant, J. C.; Iyengar, S. S.; Tomasi, J.; Cossi, M.; Millam, J. M.; Klene, M.; Adamo, C.; Cammi, R.; Ochterski, J. W.; Martin, R. L.; Morokuma, K.; Farkas, O.; Foresman, J. B.; Fox, D. J. Gaussian, Inc., Wallingford CT, 2016.

(59) Peverati, R.; Truhlar, D. G. Improving the Accuracy of Hybrid Meta-GGA Density Functionals by Range Separation. J. Phys. Chem. Lett. 2011, 2, 2810-2817.

(6o) Weigend, F.; Ahlrichs, R. Balanced basis sets of split valence, triple zeta valence and quadruple zeta valence quality for $\mathrm{H}$ to Rn: Design and assessment of accuracy. Phys. Chem. Chem. Phys. 2005, 7, 3297-305.

(61) Tomasi, J.; Mennucci, B.; Cammi, R. Quantum Mechanical Continuum Solvation Models. Chem. Rev. 2005, 105, 29993093.

(62) (a) Goldstein, S.; Michel, C.; Bors, W.; Saran, M.; Czapski, G. A critical reevaluation of some assay methods for superoxide dismutase activity. Free Radic. Biol. Med. 1988, 4, 295-303; (b) Lihi, N.; Kelemen, D.; May, N. V.; Fábián, I. The Role of the Cysteine Fragments of the Nickel Binding Loop in the Activity of the $\mathrm{Ni}$ (II)-Containing SOD Enzyme. Inorg. Chem. 2020, 59, 47724780 . 